\title{
HOT-CARGO AGREEMENTS IN THE CONSTRUCTION INDUSTRY: RESTRAINTS ON SUBCONTRACTING UNDER THE PROVISO TO SECTION 8(e)
}

\begin{abstract}
The National Labor Relations Act ${ }^{1}$ includes a general policy against secondary union activity-union pressure exerted against a neutral einployer in order to influence the labor relations of another employer. ${ }^{2}$ In 1947 the Taft-Hartley Act outlawed strikes and boycotts for secondary objectives, ${ }^{3}$ but a loophole in the Act rendered agreements aimed at secondary objectives immune froin scrutiny under the labor laws. ${ }^{4}$ These agreeinents are known as "hot-cargo" contracts, a term that arose from their original use by the Teansters Union. ${ }^{5}$
\end{abstract}

1. 29 U.S.C. $\$ \$ 141-187$ (1976 \& Supp. 1978).

2. The key anti-secondary provisions, id. $\S \S 158(\mathrm{~b})(4), 158(\mathrm{e})$, derive from the Labor-Management Relations (Taft-Hartley) Act, id. $\S$ 141-197, as amended by the Labor-Management Reporting and Disclosure (Landrum-Griffin) Act, id. §§ 151-169. Secondary activity has been defined as union action, such as threats, strikes, or boycotts, designed not to affect the labor policies of the employer at which the action is directed, but rather to influence the labor policies of another employer. See National Woodwork Mfrs. Ass'n v. NLRB, 386 U.S. 612, 644-45 (1967). To prevent this activity, section 8(b)(4)(A) of the National Labor Relations Act, 29 U.S.C. § 158(b)(4)(A) (1976), makes it an unfair labor practice for a union to strike, boycott, threaten, or coerce any person with the object of forcing that person to enter into a prohibited secondary agreement; section 8(b)(4)(B), 29 U.S.C. § 158(b)(4)(B) (1976), makes it an unfair labor practice to threaten or coerce a person with the object of forcing that person to cease domg business with another person; and section 8(e), 29 U.S.C. § 158(e) (1976), makes it an unfair labor practice for a union and an employer to enter into an agreement to refuse to handle the goods of or to cease doing bnsiness with any other person. See generally Nash, Connell "Hot Cargo" Agreements: The Supreme Court as Interpreted by the NLRB, 83 Dick. L. REv. 661, $662-66$ (1979).

3. 29 U.S.C. \& 158(b)(4) (1976).

4. The Supreme Court created this loophole with its decision in Local 1976, United Bhd. of Carpenters v. NLRB (Sand Door), 357 U.S. 93, 107-11 (1958). Congress was aware of this decision's impact on Taft-Hartley. See, e.g., S. Rep. No. 187, 86th Cong., 1st Sess. 78-79 (1959), reprinted in I NLRB, LEGISLATIVE HISTORY OF THE LABOR-MANAGEMENT REPORTING AND DISCLOSURE ACT OF 1959, at 474-75 (1959) (minority views) [hereinafter cited as LEGIs. Hist.]; H.R. REP. No. 741, 86th Cong., Ist Sess. 20-21 (1959), reprinted in I LEGIs. HisT., supra, at 778-79. See also National Woodwork Mfrs. Ass'n v. NLRB, 386 U.S. 612, 633-36 (1967).

5. The Teamsters Union inserted these provisions in its contracts with trucking firms. A company that wanted to ship goods with a trucker whose employees were represented by the Teamsters had to recognize the Teamsters to prevent his goods from becoming hot cargo-goods 
In response to widespread dissatisfaction with the labor laws' tolerance of secondary agreements, ${ }^{6}$ Congress anended the Act in 1959 by adding section $8(\mathrm{e}),{ }^{7}$ which curtails the freedom of unions and employers to make hot-cargo agreements. The amended Act does not absolutely prohibit all secondary ágreements, however. A proviso to section $8(e)$ gives a limited exception for subcontracting agreements ${ }^{8}$ between a union and an employer in the construction industry; a second proviso creates a more generous exception for the garment indus-

the Teamsters would not handle. See Fleming, Tïle VII: The Taft-Hartley Amendments, 54 Nw. U.L. REv. 666, 686 (1960). The term "hot cargo" contract has come to embrace all secondary agreements "by which the employer promises not to use the materials - or . . . the services-of nonunion employers." Pacific Northwest Chapter of the Associated Builders \& Contractors, Inc. v. NLRB, 609 F.2d 1341, 1343 n.1 (9th Cir. 1979), petition for rehearing en banc granted, No. 783469 (9th Cir. Aug. 19, 1980).

6. See Senate Select Comm. on Improper Activities in the Labor or Management Field (MCClellan CommitTeE), Final Report, S. Rep. No. 1139, 86th Cong., 2d Sess. (1960). Senator Dirksen introduced the remarks of Secretary of Labor Mitchell into the Congressional Record to illustrate the hostility to these hot-cargo clauses: "The testimony before the select committee again and again illustrated the nethod by which certain unions, particularly the Teamsters, utilized the inadequacies of the present secondary boycott provisions to force employers to do busimess with only those people approved by umion officials." 105 CONG. REC. 1730 (1959), reprinted in II LEGIS. Hist., supra note 4, at 993.

7. Section 8(e) provides:

It shall be an unfair labor practice for any labor organization and any employer to enter into any contract or agreement, express or implied, whereby such employer ceases or refrains or agrees to cease or refrain front handling, using, selling, transporting or otherwise dealing in any of the products of any other employer, or to cease doing business with any other person, and any contract or agreement entered into heretofore or hereafter containing such an agreement shall be to such extent unenforcible and void: Provided, That nothing in this subsection shall apply to an agreement between a labor organization and an eimployer in the construction industry relating to the contractimg or subcontracting of work to be done at the site of the construction, alteration, painting, or repair of a building, structure, or other work: Provided further, That for the purposes of this subsection and subsection (b)(4)(B) of this section the terms "any employer", "any person engaged in commerce or an imdustry affecting commerce", and "any person" when used im relation to the terms "any other producer, processor, or manufacturer", "any other employer", or "any other person" shall not include persons in the relation of a jobber, manufacturer, contractor, or subcontractor working on the goods or premises of the jobber or inanufacturer or performing parts of an integrated process of production in the apparel and clothing industry: Provided further, That nothing in this subchapter shall prohibit the enforceinent of any agreement which is within the foregoing exception.

Labor-Management Reporting and Disclosure Act of 1959, Pub. L. No. 86-257, \& 704, 73 Stat. 519 (1959) (codified at 29 U.S.C. \& 158(e) (1976)).

On the background of section 8(e), sce generally C. Morris, THE Developing Labor LaW 645-74 (1971); Lesnick, Job Security and Secondary Boycotts: The Reach of NLRA \$\& 8(b)(4) and 8(e), 113 U. PA. L. Rev. 1000 (1965); St. Antoine, Secondary Boycotts and Hot Cargo: A Study in Balance of Power, 40 U. DET. L.J. 189 (1962); Cominent, Subcontracting Clauses and Section 8(e) of the National Labor Relations Act, $62 \mathrm{MrCH}$. L. Rev. 1176 (1964); Cominent, Hot Cargo Clauses: The Scope of Section 8(e), 71 YALE L.J. 158 (1961).

8. This note refers to agreements between a union and an employer concerning the employer's subcontracting practices as "subcontracting agreements." 
try.9 The construction industry proviso allows a union to agree with an employer in the construction industry to restrict subcontracting at the job site to firms employing union workers. ${ }^{10}$ These agreements are secondary because they use the general contractor to pressure the subcontractors to recognize the union as the representative of the subcontractor's employees.

The purposes and scope of the construction industry proviso have long been disputed. ${ }^{11}$ The Supreme Court's decision in Connell Construction Co. v. Plumbers Local $100^{12}$ intensified the debate over the type of subcontracting agreeinent that the proviso was designed to protect. The Connell Court held that the construction industry proviso does not protect a subcontracting agreement negotiated outside of a collective bargaining context and not confined to the particular job site where the union inembers are present. ${ }^{13}$ This decision put in question the legality of commonly used construction industry subcontracting agreements. According to the General Counsel of the National Labor

9. While the construction industry proviso permits unions and einployers to enter into certain secondary agreements, and allows construction unions to exert coercive pressure to obtain such agreements, see notes 67-73 infra and accompanying text, the garment industry proviso further allows unions to enforce such agreements by coercive pressure. See Danielson v. Joint Bd. of Coat Workers, 494 F.2d 1230, 1237 (2d Cir. 1974).

10. Restrictions on subcontracting are valid, without regard to the construction industry proviso, if they are addressed to primary aims. National Woodwork Mfrs. Ass'n v. NLRB, 386 U.S. 612 (1967). Clauses that limit subcontracting to preserve traditional bargaining-unit work are primary. They seek not to change the labor policies of another einployer, but to inaintain work traditionally given to the union meinbers by their own employer. $C f$. Fibreboard Paper Prods. Corp. v. NLRB, 379 U.S. 203 (1964) (the contracting out of work that bargaining-unit employees traditionally perform is a mandatory subject of bargaining). Similarly, area-standards or unionstandards clauses, which require a subcontractor to pay wages at the prevailing union rate, are lawful primary clauses; they are designed to discourage subcontracting and to prevent the erosion of negotiated standards. See Comment, Picketing for Area Standards: An Exception to Section 8(b)(7), 1968 DukE L.J. 767. By contrast, union-signatory subcontracting clauses (particularunion clauses), which restrict subcontracting to firms that have a contract with the union that has signed the subcontracting agreement, are secondary. They seek to widen the union's representation of workers by compelling subcontracting firms to recognize the union. These clauses advance general union aims, rather than specific objectives of the bargaining unit. See Heavy, Highway, Bldg. \& Constr. Teamsters Comm. (Cal. Dump Truck Owners Ass'n), 227 N.L.R.B. 269, 276 (1976) (Member Fanning, dissenting in part). A provision phrased as a union-standards clause may be construed as a union-signatory clanse if the terms with which the subcontractor inust comply inatch too closely those of the signatory union. See Carpenters Local 944 (Woelke \& Romero Framing, Inc.), 239 N.L.R.B. 241 (1978), enforced as modified sub nom. Pacific Northwest Chapter of the Associated Builders \& Contractors v. NLRB, 609 F.2d 1341 (9th Cir. 1979), petition for rehearing en banc granted, No. 78-3469 (9th Cir. Aug. 19, 1980).

11. See, e.g., National Woodwork Mfrs. Ass'n v. NLRB, 386 U.S. 612 (1967); Northeasteru Ind. Bldg. and Constr. Trades Council (Centlivre Village Apartments), 148 N.L.R.B. 854 (1964), enforcement denied, 352 F.2d 696 (D.C. Cir. 1965).

12. 421 U.S. 616 (1975).

13. Id. at 635 . 
Relations Board (NLRB), Connell "significantly narrowed the scope of the proviso from the broader interpretation previously given it by the Board and the Courts."14

Before Connell the NLRB had considered a subcontracting agreement lawful as long as it was negotiated im a collective bargaining context. ${ }^{15}$ After Connell the question was more complex. First, Connell left open the possibility that in order to be sheltered by the proviso, a subcontracting agreement must not only be negotiated in a collective bargaining context, but must also be limited to particular sites where union members were working. ${ }^{16}$ Second, Connell raised questions about the lawfulness of a subcontracting agreement that required a subcontractor to recognize not just any union but the particular union that had made the subcontracting agreeinent. ${ }^{17}$ Finally, Connell did not make clear whether a prehire agreement, the standard type of collective bargaining agreement in the construction industry, would satisfy the requirement that the union and employer have a collective bargaiming relationslin. ${ }^{18}$

Two courts of appeals recently faced these issues. A panel of the Court of Appeals for the Ninth Circuit, in Pacific Northwest Chapter of

14. NLRB General Counsel's Memorandum on Connell, Guidelines for Handling Section 8(e) Construction Industry Proviso Cases Under the Supreme Court's Connell Decision at 1 (1976), reprinted in LAB. REL. YEARBOOK 295 (1976) [heremafter cited as NLRB General Counsel's Memorandum]. Several cases after Connell held that a collective bargaining agrecment was not sufficient to protect a secondary subcontracting clause under the construction industry proviso unless the clause was limited to particular job sites where union employees were present. See notes $150-58$ infra and accompanying text.

15. See Plunibers Local 100 (Hagler Constr. Co.), NLRB Case No. 16-CC-447 (May 1, 1974). The General Counsel's Memorandum supporting his decision not to issue a complaint agaimst Plumbers Local 100 is reprinted in LAB. REL. YeARBooK 298 (1974).

16. See 421 U.S. at 633 . See also note 108 infra.

17. See 421 U.S. at $630-35$. By stressing the fact that Congress did not wish to foster topdown organizing, the Court cast doubt on subcontracting agreements that specify a particular umion rather than allowing any union. See also Donald Schriver, Inc. v. NLRB, 635 F.2d 859, 884-86 (D.C. Cir. 1980); Pacific Northwest Chapter of the Associated Builders \& Contractors, Inc. v. NLRB, 609 F.2d 1341, 1350 n.8 (9th Cir. 1979), petition for rehearing en banc granted, No. 783469 (9th Cir. Aug. 19, 1980).

18. For a definition of a prehire agreement, see notes 105-06 infra and accompanying text. The Court suggested that a prehire agreement under section 8(f), 29 U.S.C. \& $158(f)$ (1976) might be adequate. Rejecting an argument that the NLRB had already decided the issue in Connell (whether a subcontracting agreement fell within the construction industry proviso even if the umion that negotiated it had no collective bargaining relationship with the employer), the Court distinguished Los Angeles Bldg. \& Constr. Trades Council (B \& J Investment Co.), 214 N.L.R.B. 562 (1974), by noting that it may have involved a prehire agreement. 421 U.S. at $631-32 \mathrm{n} .10$. The Court's reference, however, did not purport to decide the issue. See Donald Schriver, Inc. v. NLRB, 635 F.2d 859, 873 n.22 (D.C. Cir. 1980). 
the Associated Builders and Contractors v. $N L R B,{ }^{19}$ rejected the view that a collective bargaining relationship alone privileges a subcontracting agreement under the construction industry proviso to section 8(e). The court reasoned that the sole purpose of the proviso is to allow agreements designed to alleviate the friction between union and nonunion einployees working shoulder to shoulder on a job site. ${ }^{20}$ A subcontracting agreement, even in a collective bargaining context, thus may not lawfully restrict subcontracting to union firms except in the common-situs situation. ${ }^{21}$ The court indicated that were an agreenent appropriately limited, however, it could specify a particular union that subcontractors inust recognize. ${ }^{22}$ The court did not address the sufficiency of prehire agreements.

The Court of Appeals for the District of Colunbia Circuit, in Donald Schriver, Inc. v. $N L R B,{ }^{23}$ disagreed with the Ninth Circuit on the scope of the construction industry proviso. Donald Schriver held that two concerns lie behind the proviso: first, to enable unions to avert common-situs tension; and second, to permit standardization of working conditions and protection of the employinent opportunities of union inembers. ${ }^{24}$ The second purpose justifies subcontracting agreements that apply to all job sites at which work is done by the signatory union's craft. The court also uplield subcontracting restraints on otler crafts, because these restraints lielp avoid common-situs tension. ${ }^{25} \mathrm{Fi}$ nally, Donald Schriver lield that a prehire agreement ineets the collective bargaining requirement set out in Connell. ${ }^{26}$

The conflict between Pacific Northwest and Donald Schriver steins from divergent views of the purposes behind the construction industry proviso and of the proper interpretation of Connell. This note examines the scope of the proviso. First, the note sketches the background of the proviso and its application by the courts. Second, the note analyzes the annbiguities in the Connell Court's reasoning and the confusion that Connell has engendered. Finally, the note turns to the recent decisions by the Courts of Appeals for the Ninth and District of Colunibia Cir-

19. 609 F.2d 1341 (9th Cir. 1979), petition for hearing en banc granted, No. 78-3469 (9th Cir. Aug. 19, 1980).

20. 609 F.2d at $1349-50$.

21. The common-situs situation consists of the presence of many employers on a single job site. For an example of a common-situs arrangement, see Denver Bldg. \& Constr. Trades Council v. NLRB, 341 U.S. 675 (1951).

22. $609 \mathrm{~F} .2 \mathrm{~d}$ at $1350 \mathrm{n} .8$. The court believed that frictions on the jobsite might occur as easily between members of different unions as betwcen union and nonunion workers.

23. 635 F.2d 859 (D.C. Cir. 1980).

24. Id. at 880 .

25. Id. at 883-84.

26. Id. at $872-73$. 
cuits. The note argues that the Pacific Northwest court failed to consider adequately the legislative history of section 8(e), the pattern of bargaining in the construction industry, and the interaction of the applicable labor laws. The Donald Schriver court displayed greater appreciation of the special circumstances of the construction industry, and therefore framed a more appropriate response to the post-Connell issues. In conclusion, the note explores the tension between Donald Schriver and Connell concerning the effect of subcontracting agreements on nonumion firms, and suggests that Connell be limited to accommodate the construction industry's reahities that Donald Schriver recognized.

\section{The History of the Construction Industry Proviso}

\section{A. Prelude to Section 8(e): Denver Building Trades and Sand Door.}

The NLRB did not assume jurisdiction over the construction industry until the Taft-Hartley amendments of $1947 .{ }^{27}$ Hence, the pattern of collective bargaining between construction unions and employers developed independently of doctrines that the Board imposed on other imdustries. When the Board applied the Act to construction unions after 1947, conflicts emerged between the unique features of the construction industry and the general provisions of the Act. ${ }^{28}$

27. Labor-Management Relations (Taft-Hartley) Act, Pub. L. No. 80-101, 61 Stat. 136 (1947) (current version at 29 U.S.C. $\$ \$ 151-166$ (1976 \& Supp. II 1978)). The NLRB declined to assert jurisdiction over the construction industry under the original Wagner Act, ch. 372, $\$ 81-19,49$ Stat. 449 (1935), without explaining its reasons. Johns-Manville Corp., 61 N.L.R.B. 1 (1945). See also In re Brown \& Root, Inc., 51 N.L.R.B. 820 (1943). After Taft-Hartley, the Board responded to the express intent of Congress, see S. REP. No. 105, 80th Cong., 1st Sess. 22 (1947), by taking jurisdiction over construction-mdustry cases. Plumbing Contractors Ass'n, 93 N.L.R.B. 1081 (1951). See also Fleming, supra note 5, at 702-03.

28. See Fleming, The Building Trades and Tille VII of LMRDA, in SYMPosium ON THE LABOR-MANAGEMENT REPorting AND Disclosure ACT of 1959 at 1032 (R. Slovenko ed. 1961). Prior to the Taft-Hartley Act, the construction industry had typically hired through hiring halls run by the construction unions. Id. 1035-36. This practice enabled the unions to ensure that all employees on the job were umion nembers. Congress moved against such "closed shops" in Taft-Hartley, and provided that union-security agreeinents-agreements requiring that an employee join a union-could not require an employee to join a union until he had been working for 30 days. Pub. L. No. 80-101 \& 8(a), 61 Stat. 136 (1947) (codified at 29 U.S.C. \$ 158(a)(3) (1976)). In the construction industry, however, many jobs last less than 30 days. Fleming, supra, at 1036. The Board was therefore constantly faced with umion subterfuges to avoid Taft-Hartley, and its efforts to enforce the Act were generally frustrated. Id. In 1956 the Board clamped down and required a union to reimburse dues collected under an illegal closed-shop agreement. Plumbers Local 231 (Brown-Olds Plunibing \& Heating Corp.), 115 N.L.R.B. 594, 597 (1956) (a closed-shop agreement that required the einployer not to hire a person unless the umion referred him was held unlawful). The use of this remedy generated so much controversy that it was suspended until 
$N L R B$ v. Denver Building and Construction Trades Council ${ }^{29}$ highlighted one such problem. In Denver Building Trades a general contractor awarded an electrical subcontract to a subcontractor who employed nonunion labor. Other subcontractors on the site, as well as the general contractor, were union firms. The union workers picketed to protest the presence of nonunion workers on the site. Giving in to the pressure, the general contractor terminated the employment of the nonunion subcontractor. ${ }^{30}$ The subcontractor then filed unfair labor practice charges with the NLRB. The Board found that the unions had used unlawful secondary pressure against a neutral employer-'the general contractor-with the object of influencing the labor policies of the nonunion subcontractor. The Board therefore ordered the unions to cease and desist from the unlawful picketing. ${ }^{31}$ The Suprente Court agreed with the Board, holding that the picketing constituted secondary pressure in violation of the Taft-Hartley Act. ${ }^{32}$

In construing the Taft-Hartley Act to prohibit common-situs picketing, ${ }^{33}$ the Denver Building Trades Court rejected the argument that all employees on a construction site work for the general contractor. ${ }^{34}$ The Court noted that the general contractor brings the subcontractor onto the site and supervises his work, but considered it well settled that the two are imdependent contractors. ${ }^{35}$ Pressure on the general contractor to influence labor policies of the subcontractor thus breaches the antisecondary provisions of the Act. ${ }^{36}$ In dissent, Justice Douglas argued

1958. Fleming, supra, at 1036 . In 1959 Congress attempted to adjust the labor laws to construction industry bargaining practices by enacting section $8(\mathrm{f})$, which legalized prehire agreements. Labor-Management Reporting and Disclosure (Landrum-Griffin) Act of 1959, Pub. L. No. 86257, § 705(a), 73 Stat. 543 (codified at 29 U.S.C. $\$ 158(f)(1976)$ ).

29. 341 U.S. 675 (1951).

30. Id. at 677-79.

31. Denver Bldg. \& Constr. Trades Council (Gould \& Preisner), 82 N.L.R.B. 1195 (1949).

32. 341 U.S. at 689.

33. Id. at 689-90. Common-situs picketing occurs when one union pickets at a multi-employer construction site, thus inducing members of all unions at the site to walk off the job. See Cominent, The Impact of the Taft-Hartley Act on the Building and Construction Industry, 60 YALE L.J. 673 (1951).

34. 341 U.S. at $689-90$.

35. Id.

36. During the Senate debate on the conference report accompanying the Landrum-Griffin Act, Senator Morse criticized the Denver Building Trades decision for neglecting the close relationship between contractors and subcontractors on a construction site. 105 CoNG. REC. 17,881 (1959) (reinarks of Sen. Morse), reprinted in II LEGIS. HIST., supra note 4, at 1425 . Unlike the true neutral einployers that the secondary-boycott restrictions were designed to protect, the general contractor is, in effect, entirely in control of the kind of labor relations taking place on a job site which he runs. He lets subcontracts based on price, responsibility, and the ability to handle labor relations. 
that common-situs picketing does not constitute secondary activity. ${ }^{37}$ Common-situs picketing, he stated, reflects only the traditional union demand that "union men not be compelled to work alongside nonunion men on the same job." 38 The unions picketed because the general contractor brought nonunion workers on the job site; that a subcontractor was the means of accomplishing this was immaterial.

The failure of Denver Building Trades to accommodate the interest of unionized construction workers in working on an all-union site did not end union efforts to attain that goal. Denver Building Trades settled that secondary pressure tactics violate Taft-Hartley. Yet voluntary agreements between unions and employers to restrict subcontracting to union firms appeared to be lawful under Local 1976, United Brotherhood of Carpenters v. NLRB (Sand Door). ${ }^{39}$

In Sand Door two general contractors entered into a collective bargaining agreement with the United Brotherhood of Carpenters and Jomers. The agreement provided that the carpenters need not work on naterial produced by nonunion workers. ${ }^{40}$ Despite the agreement, the general contractors purchased doors from the Sand Door and Plywood Company, a distributor of nonunion doors. When union representatives discovered this, they directed union members to stop working. Sand Door filed charges alleging that the carpenters had exerted pressure agamst it to prevent it from doing busmess with the nonunion inanufacturer; the carpenters raised the hot-cargo contract as a defense. ${ }^{41}$

The Court held that an einployer's voluntary agreement not to purchase doors made by a nonunion company could not be enforced by coercive union tactics. ${ }^{42}$ The hot-cargo agreement itself, however, did Id.

The Board and the Supreme Court, in the Denver Building Trades case, held that this very unified relationship was a group of separate employers; hence, a primary dispute with one of them would have to be conducted in a way not to induce the employees of the other contractors on the job to refrain from work. This case ... involved an electrical contractor paying 42 cents an hour below the negotiated area rate. That such a subcontractor was on the job at all was directly due to a decision by the general contractor, and it is difficult to see how a union induceinent of his employees to leave work can be justly prohibited . . . .

37. 341 U.S. at 692 (Douglas, J., dissenting).

38. $I d$.

39. 357 U.S. 93 (1958).

40. Id. at 95 .

41. Id. at $94-96$.

42. Id. at 104-05. The Court reasoned that the secondary boycott provisions prohibited only coercive secondary pressure. Hence, a voluntary agreement by an employer did not violate the Act. If an employer did not honor a voluntary agreement, however, the element of voluntariness ceased. Union action at that point contravened the poticy against involuntary cessations of doing 
not constitute illegal secondary activity. ${ }^{43}$ Sand Door thus enabled unions to enter into agreements with employers to influence the labor policies of other employers. ${ }^{44}$ A union could attain through an agreement exactly what Denver Building Trades declared it could not achieve through pressure: it could prevent a general contractor from employing nonunion subcontractors. This arrangement satisfied neither construction unions nor employers. The unions wanted to eliminate the ban on common-situs picketimg; 45 the employers sought an additional ban on secondary subcontracting agreements. ${ }^{46}$ Congress addressed these matters when it amended the Act by passing the Labor-Management Reporting and Disclosure Act of 1959, popularly known as the LandrumGriffin Act. ${ }^{47}$

\section{B. The Genesis of the Construction Industry Proviso to Section $8(e)$.}

The Landrum-Griffin Act combimes two distmct types of provisions. 48 One group of sections regulates the internal affairs of unions to promote union democracy. ${ }^{49}$ A second set, amending the Taft-Hartley Act, ${ }^{\text {s0 }}$ tightens Taft-Hartley's restrictions on organized labor's activities. $^{51}$ Section $8(\mathrm{e})^{52}$ is of the second type. The aim of section $8(\mathrm{e})$, which makes it an unfair labor practice for a labor organization and an employer to agree not to do business with a third person, is to outlaw secondary agreements. ${ }^{53}$

business with another person to influence that person's labor relations. The Court therefore measured freedom of choice at the time the protested union action occurred. Id.

43. Id. at 108 .

44. Although Sand Door actually dealt with a product-boycott agreement, both the Court and the Board have acknowledged that Sand Door apphed generally to secondary agreements. See NLRB v. Enterprise Ass'n of Pipefitters, 429 U.S. 507, 516 (1977) ("[T]he making and voluntary observance of [hot cargo] contracts were not contrary to law at the time that Sand Door was decided"); Metropolitan Dist. Council, 149 N.L.R.B. 646, 658 (1964) (discussing "the then-lawful 'hot-cargo' clause in the Sand Door case").

45. See Note, The Antitrust Exemption for Labor Organizations in the Construction Industry, 2 WhITTIER L. REV. 285, 289-90 (1980).

46. See Fleming, supra note 5 , at 682 .

47. Pub. L. No. 86-257, 73 Stat. 519 (1959) (codified at 29 U.S.C. $\$ \$ 151-169$ (1976 \& Supp. II 1978)).

48. See generally Aaron, The Labor-Management Reporting and Disclosure Act of 1959 (pts. 1-2), 73 HaRv. L. Rev. 851, 1086 (1960).

49. Labor-Management Reporting and Disclosure Act, tits. I-IV, Pub. L. No. 86-257, 73 Stat. 519 (1959) (current version codified in scattered sections of 29 U.S.C.).

50. Id., tit. VII (current version codified at 29 U.S.C. $\$ \S 151-169$ (1976 \& Supp. II 1978).

51. See C. MORRIs, supra note 7, at 51-54; Cox, The Landrum-Griffin Amendments to the National Labor Relations Act, 44 MINN. L. REv. 257, 260 (1959).

52. The text of section 8(e), 29 U.S.C. $§ 158(\mathrm{e})(1976)$, is set out in note 7 supra.

53. The Supreme Court had implied that secondary agreements were lawful in Local 1976, United Blıd. of Carpenters v. NLRB (Sand Door), 357 U.S. 93 (1958). See notes 39-44 supra and accoinpanying text. 
Congress prohibited secondary agreements principally because they enmesh a neutral employer in a labor struggle between a union and the primary employer. ${ }^{54}$ But the neutral (secondary) employer is not the only person the secondary agreement imfluences; the agreement also affects the employees of the primary employer. By threatening the primary employer with the loss of busmess if it does not recognize the union, secondary agreements tend to organize from the top down. ${ }^{55}$ Rather than appealing directly to the workers to form a union, topdown organizing imposes the union on both the workers and their employer, depriving the workers of their right to choose or refrain from choosing a bargaining representative. ${ }^{56}$ As a practical matter, once the employer recognizes the union, all the employees may be forced to submit to that union's representation. ${ }^{57}$ Section 8(e) was part of Congress's scheme to limit top-down organizing. ${ }^{58}$ The scheme not only restricted hot-cargo contracts, but also regulated primary recognitional picketing $^{59}$ and proscribed secondary economic pressure. ${ }^{60}$

The Senate origmally proposed that section $8(e)$ cover only the transportation industry, in response to the Teamsters Union's notorious

54. See National Woodwork Mfrs. Ass'n v. NLRB, 386 U.S. 612, 635-38 (1967). The National Woodwork Manufacturers Court stated that both section 8(b)(4)(B), 29 U.S.C. \& 158(b)(4)(B) (1976), and section 8(e), 29 U.S.C. \& 158 (e) (1976), were designed to insulate neutral secondary employers from pressure to boycott a primary employer. 386 U.S. at 635 .

55. See Connell Constr. Co. v. Plumbers Local 100, 421 U.S. 616, 632 (1975).

56. Section 7 of the Natioual Labor Relations Act, 29 U.S.C. $\S 157$ (1976), secures this right. Section 7 provides:

Employees shall have the right to self-organization, to form, join, or assist labor organizations, to bargain collectively through representatives of their own choosing, and to engage in other concerted activities for the purpose of collective bargaining or other mutual aid or protection, and shall also have the right to refrain from any or all of such activities except to the extent that such right may be affected by an agreement requirimg membership in a labor organization as a coudition of employment as authorized in secId. tion 158(a)(3) of this title.

57. The Act authorizes union-security agreements that require an employee in a union shop to join the union within thirty days of his employment. 29 U.S.C. $\$ 158(a)(3)$ (1976). In the construction industry, section $8(f)$ permits this period to be shortened to seven days. 29 U.S.C. $\$ 158($ (f) (1976). State right-to-work laws, however, may prohibit union-security agreements. 29 U.S.C. \& 164(b) (1976).

58. See Connell Constr. Co. v. Plunibers Local 100, 421 U.S. 616, 632 (1975).

59. See 29 U.S.C. § 158(b)(7) (1976). A union may picket an einployer with the object of compelling that employer to recognize the union. Although this picketing is primary, it still may constitute top-down organizing because the einployer may recognize the union, without regard for the employees' wishes, in order to end the picketing. $C f$. Teamsters Local 695 v. Vogt, Inc., 354 U.S. 284 (1957) (the Court upheld a state court injunction against a union's picketing for recognition, when the picketing was designed to influence the employer to pressure his employees to join the union).

60. See 29 U.S.C. $\$ \S 158(\mathrm{~b})(4)(B), 159$ (c) (1976). 
use of hot-cargo agreements. ${ }^{61}$ The Teamsters had used their control over the trucking imdustry to win agreements entitling them to refuse to handle goods of nonunion manufacturers. Because these manufacturers depended on the trucking imdustry to transport their products, the Teamsters could exert pressure on them to recognize Teamsters locals. ${ }^{62}$ The House, however, saw a broader evil in secondary agreements, and countered with a sweeping condemnation of secondary agreements in all industries. ${ }^{63}$ In conference the House version of section 8(e) prevailed, but the Senate insisted on an exception for the construction industry and an even broader exception for the garment mdustry. ${ }^{64}$ The construction industry proviso states:

Provided, That nothing in this subsection shall apply to an agreement between a labor organization and an employer in the construction mdustry relating to the contracting or subcontracting of work to be done at the site of the construction, alteration, painting, or repair of a building, structure, or other work . . . .65

Few legislators spoke on the construction industry proviso, and the remarks of those who did were brief. The NLRB and the courts have thus looked to the general structure of the labor laws as well as to the legislative history for guidance in interpreting the proviso.

\section{Pre-Connell Interpretations of the Proviso.}

Three developments in the interpretation of section 8(e) preceded the Supreme Court's Connell decision. The courts at first uniformly rejected the NLRB's narrow construction of the proviso and eventually persuaded the Board to adopt a broader view of it. Courts then began to limit the contours of the proviso, finding that the Board's interpretation went beyond the purposes Congress had for the proviso. Finally, the Supreme Court decided a major section 8(e) case, in the course of

61. S. 1555, 86th Cong., 1st Sess. \& 707(a) (1959), reprinted in I LEGis. HIST., supra note 4, at 582. As originally proposed, the subsection read:

(e) It shall be an unfair labor practice for any labor organization and any employer who is a common carrier subject to Part II of the Interstate Commerce Act to enter imto any contract or agreement, express or implied, whereby such employer ceases or refrains or agrees to cease or refrain from handling, using, or transporting any of the products of any other employer or to cease doing business with the saine.

Id. On the original motivation of the Senate to reach only the Teamsters with its prohibition of hot-cargo clauses, see National Woodwork Mfrs. Ass'n v. NLRB, 386 U.S. 612,636 (1967); S. REP. No. 187, 86th Cong., 1st Sess. 78, reprinted in I LEGIS. HIST., supra note 4, at 475.

62. See S. REP. No. 187, 86th Cong., 1st Sess. 78, reprinted in I LEGIS. HIST., supra note 4, at $474,475$.

63. See H.R. 8400, 86th Cong., 1st Sess. § 705(b)(1) (1959), reprinted in I LEGIS. HisT., supra note 4 , at 683 .

64. See Conf. Comm. ReP., H.R. Rep. No. 1147, 86th Cong., 1st Sess. 39-40 (1959), reprinted in I LEGIS. HIST., supra note 4, at 934, 943-44.

65. 29 U.S.C. \& 158(e) (1976). 
which the Court touched on the purposes of the construction industry proviso. ${ }^{66}$

The first development concerned the Board's initial reluctance to permit unions to pressure employers to accept subcontracting agreeinents that the construction industry proviso concededly protected. ${ }^{67}$ Section $8(b)(4)(A)^{68}$ makes it an unfair labor practice to conipel an enployer to enter into an agreenient prohibited by section 8(e). The Board found that section $8(\mathrm{~b})(4)(\mathrm{A})$ and $8(\mathrm{e})$ combined to prohibit union pressure for subcontracting agreements. ${ }^{69}$ This analysis rested on the view that Congress intended to permit only voluntary subcontracting agreements. ${ }^{70}$ Three courts of appeals rejected this view, holding that section $8(\mathrm{~b})(4)(\mathrm{A})$ prohibited pressure to obtain secondary agreeinents proscribed by section $8(\mathrm{e})$ but did not reach lawful sccondary agreeinents such as those shielded by the construction industry proviso.71 In 1964 the Board acceded to this view. In Northeastern Indiana Building and Construction Trades Council (Centlivre Village Apartments), ${ }^{72}$ the Board recognized that the congressional scheine governing construction industry subcontracting allowed unions to use economic pressure to secure agreenients protected by the proviso. After Centlivre the Board began to construe the proviso expansively. ${ }^{73}$

The second step in defining the scope of the proviso was taken when courts were asked to determine the ineaning of "job site" work. By its terms the construction industry proviso protects only those agreeinents between unions and employers that relate to work on a construction site. ${ }^{74}$ In Drivers Local 695 v. NLRB ${ }^{75}$ the Court of Appeals for the District of Colunibia Circuit held unlawful an agreenient between a

66. See National Woodwork Mfrs. Ass'n v. NLRB, 386 U.S. 612 (1967).

67. See Construction, Prod., \& Maintenance Laborers Local 383 (Colson \& Stevens Constr. Co.), 137 N.L.R.B. 1650 (1962), enforcement denied, 323 F.2d 422 (9th Cir. 1963).

68. 29 U.S.C. $\$ 158(\mathrm{~b})(4)(A)(1976)$.

69. See Construction, Prod., \& Maintenance Laborers Local 383 (Colson \& Stevens Constr. Co.), 137 N.L.R.B. 1650 (1962), enforcement denied, 323 F.2d 422 (9th Cir. 1963).

70. Id.

71. See Essex County \& Vicinity Dist. Council v. NLRB, 332 F.2d 636 (3d Cir. 1964); Orange Belt Dist. Council v. NLRB, 328 F.2d 534 (D.C. Cir. 1964); Construction, Prod., \& Maintenance Laborers Local 383 v. NLRB, 323 F.2d 422 (9th Cir. 1963).

72. 148 N.L.R.B. 854 (1964), enforcement denied on other grounds, 352 F.2d 696 (D.C. Cir. 1965).

73. See Plumbers Local 100 (Hagler Constr. Co.), NLRB Case No. 16-CC-447 (May 1, 1974). The General Counsel's menorandum supporting his decision not to issue a complaint against Plumbers Local 100 is reprinted in LAB. REL. YeARBOoK 298 (1974).

74. See 29 U.S.C. $\$ 158(\mathrm{e})$ (1976). The text of the proviso is set out at text accompanying note 65 supra. "The proviso does not exempt from section $8(\mathrm{e})$ agreements relating to supplies or other products or materials shipped or otherwise transported and delivered on the site of construction." Conf. Comm. ReP., supra note 64, at 39, reprinted in I LEGIS. Hist., supra note 4, at 943.

75. 361 F.2d 547 (D.C. Cir. 1966). 
union and an employer that permitted the employees to honor a secondary picket line. ${ }^{76}$ Because this amounted to an authorization of a secondary strike, it fell within section 8(e). The union, which represented truck drivers transporting ready-mix concrete, argued that the construction industry proviso sheltered the agreement. This contention required the court to determine whether Congress intended the job-site limitation in the proviso to cover suppliers of concrete. To answer this question the court examined the proviso's purposes. ${ }^{77}$ The court concluded that "the purpose of the section 8(e) proviso was to alleviate the frictions that may arise when union neen work continuously alongside nonunion men on the same construction site."78 Because drivers delivering concrete worked only briefly on the construction site, the friction feared by Congress would not develop. Hence, the proviso did not legitimate the agreement. The significance of Drivers Local 695 is that it saw a single purpose for the proviso: the avoidance of job-site friction. ${ }^{79}$

The final pre-Connell development was the Supreme Court's decision in National Woodwork Manufacturers Association v. NLRB. ${ }^{80}$ In National Woodwork Manufacturers, a general contractor had an agreement with the Carpenters Interuational Union that union carpenters did not have to handle prefitted doors. Although the contractor's job specifications did not require prefitted doors, it obtained them anyway. Upon the carpenters' refusal to hang the doors, the contractor acquired doors to be fitted on the job site. The National Woodwork Manufacturer's Association then filed unfair labor practice charges against the union with the NLRB, alleging that the refusal-to-liandle clause vio-

76. The court construed the agreement as sanctioning a secondary boycott against the primary employer. $I d$. at 549 . This situation would arise when a union that has a dispute with a subcoutractor pickets a general contractor to induce him not to do business with the subcontractor. If the general contractor does not discipline his employees when they refuse to cross the picket line, he has in effect authorized a secondary boycott.

77. Id. at 552 .

78. Id. at 553 .

79. The Drivers Local 695 court's analysis of the proviso did not depend on a reading of the legislative history; rather, the court relied on Essex County \& Vicinity Dist. Council v. NLRB, 332 F.2d 636 (3d Cir. 1964); Justice Douglas's dissent in NLRB v. Denver Bldg. and Constr. Trades Council, 341 U.S. 675, 692 (1951); and two law review comments: Comment, The Landrum-Griffin Amendment: Labor's Use of the Secondary Boycott, 45 CORNELL L.Q. 724 (1960); Comment, Hot Cargo Agreements Under the National Labor Relations Act: Analysis of Section 8(e), 38 N.Y.U. L. REV. 97 (1963). Alternative reasons for the proviso, such as a desire to preserve a pattern of collective bargaining, were not discussed despite statements indicating such a policy by Senator John Kennedy, the proponent of the proviso. See 105 ConG. Rec. 17,899 (1959) (remarks of Sen. Kennedy), reprinted in II LEGIS. HisT., supra note 4, at 1432. See also Counell Constr. Co. v. Plumbers Local 100, 421 U.S. 616, 628-29 (1975) (dismissing such remarks as "bare references").

80. 386 U.S. 612 (1967). Justice Breunan wrote the majority opinion. Justice Stewart, joined by three other justices, dissented. See 386 U.S. at 650 (Stewart, J., dissenting). 
lated section 8(e). ${ }^{81}$ The Court of Appeals for the Seventh Circuit accepted this contention 82 but the Supreme Court reversed, holding that section 8(e) proscribed only secondary agreements. ${ }^{83}$ Agreements that restricted subcontracting solely to protect the jobs of union ineinbers were primary agreements, because they aimed to preserve the work of the bargaining unit. The Court thus upheld the union's refusal-to-handle clause. ${ }^{84}$

Although National Woodwork Manufacturers did not involve the construction industry proviso, the Court drew upon it to support the conclusion that section $8(\mathrm{e})$ prohibited only secondary agreenients. ${ }^{85}$ The Court construed the proviso as "a ineasure designed to allow agreements pertaining to certain secondary activities on the construction site because of the close coininunity of interests there . . ."86 The Court illuminated the ineaning of "close coininunity of interests" by citing a case that interpreted the proviso as a grant to construction unions "in recognition of . . . sporadic work stoppages occasioned by the traditional refusal of craft unionists to work alongside non-union men on the saine project." 87 The Court also cited a law review comment that spelled out the need for all crafts on a job to act collectively in order to compel the general contractor not to subcontract to nonunion firms. ${ }^{88}$

81. Id. at 615-16.

82. 354 F.2d 594 (7th Cir. 1965), rev'd, 386 U.S. 612 (1967).

83. The Court stated that secondary agreements can be identified by considering: whether, under all the surrounding circumstances, the Union's objective was preservation of work for [the contracting einployer's] einployees, or whether the agreements . . . were tactically calculated to satisfy union objectives elsewhere. . . . The touchstone is whether the agreement or its maintenance is addressed to the relations of the contracting employer vis-á-vis his own employees.

386 U.S. at $644-45$ (footnotes omitted).

84. Id. at 646; $c$. NLRB v. Pipefitters Local 638, 429 U.S. 507 (1977) (the union violated the secondary boycott prohibitions of section 8(b)(4) by picketing a subcontractor in order to enforce a valid primary work-preservation agreenent, when the general contractor and not the subcontractor had the sole right to control the assignment of the work that the union sought).

85. 386 U.S. at 639 . The construction industry proviso's job-site limitation indicated to the Court that section 8(e) prohibits only secondary agreements. The Court reasoned that the legislative history does not suggest that Congress intended to allow construction unions to protect their work against job-site prefabrication but not against off-job-site prefabrication. These difficulties disappear if the body of section 8(e) is read to prohibit only secondary agreements, and the proviso is read to permit secondary agreements in relation to the job site, where construction urions have a special interest in restricting employment to union members. Id. at 637-39.

86. Id. at 638-39.

87. Essex County \& Vicinity Dist. Council v. NLRB, 332 F.2d 636, 640 (3d Cir. 1964) (a strike to obtain an agreement lawful under section $8(e)$ does not violate section $8(\mathrm{~b})(4)(A))$, ciled in 386 U.S. at 639 n.32.

88. See Comment, supra note 33, at 684-89, cired in 386 U.S. at 639 n.32.

With employers numerous, employment of short duration, and individual craft unity small on any one project, umions have traditionally been forced to rely on the coopera- 
The net effect of these developments was that the Board adopted a broad reading of the construction industry proviso, which the courts began to narrow to accord with the perceived congressional intent of preserving job-site harmony. These two views clashed in Connell Construction Co. v. Plumbers Local 100.89

\section{Connell Construction Co. v. Plumbers Local 100}

\section{A. The Facts and Holding of Connell.}

The Connell case arose out of a campaign mounted by the Plumbers and Steamfitters Union to be recognized as the representative of employees of the mechanical subcontractors in the Dallas area. Rather than approach the employees directly, the Plunibers adopted a relatively novel tactic designed to organize front the top down. ${ }^{90}$ They sought an agreement with the general contractors in the Dallas area, including Connell, that the general contractors would subcontract work within the trade jurisdiction of the Plumbers only to subcontractors that recognized Plumbers Local 100. The Plunibers did not intend to represent the general contractors' own employees. In fact, the Plumbers presented the proposed agreenent only to general contractors who did not employ workers within the Plumbers' trade jurisdiction. In order to induce Connell to sign the agreement, a simgle representative of the Plumbers picketed a Connell job site. After 150 workers walked off the job, Connell gave in and signed the agreement. He then sued to void the agreenent on antitrust grounds. The union raised the defense that the construction imdustry proviso authorized the agreement.91

tiou of all workers ou a job in order to bring pressure on any particular employer. Thus where oue subcontractor refuses to hire union men, the spurned union pickets the entire project to induce the union employees of other subcontractors on the job to walk out. This in turn is designed to compel the general contractor to sever relations with the nonunion subcoutractor.

Comment, supra uote 33 , at 688 .

89. 421 U.S. 616 (1975).

90. The tactic the Plumbers used in Connell was not their first atteinpt to organize the mechanical subcontractors. An earlier case, Dallas Bldg. \& Constr. Trades Council v. NLRB, 396 F.2d 677 (D.C. Cir. 1968), dealt with the Trade Council's picketing of general contractors in Dallas to obtain subcontracting agreemeuts. Because the general contractors had a collective bargaining agreement with some of the constituent crafts of the Trades Council, the court lield that the picketing was recognitioual, and that it therefore violated section $8(b)(7)$ because it interfered with the representation of the general contractors' employees by another union. The court hinted, lowever, that a uniou could avoid the section $8(b)(7)$ issue by picketing a general contractor who did not employ members of the picketing union's craft. 396 F.2d at $682 \mathrm{n} .8$. This suggestion resulted in the picketing held unlawful in Connell. St. Antoine, Connell: Antitrust Law at the Expense of Labor Law, 62 VA. L. Rev. 603, 625-26 (1976). Professor St. Antoine described this as a "relatively novel organizatioual tactic." $I d .628$.

91. 421 U.S. at 618-21. Connell originally filed suit in state court, alleging that the agreement violated Texas antitrust law. The Plunibers removed the action to federal court; Connell then 
The Supreme Court held that the agreement fell outside of the proviso, and that the Plumbers therefore could not use the proviso as a defense against an antitrust suit. ${ }^{92}$ Justice Powell, for the inajority, ${ }^{93}$ construed the construction industry proviso as extending "only to agreeinents in the context of collective bargaining relationships and, in light of congressional references to the Denver Building Trades problem, possibly to common-situs relationships on particular job sites as well."94 Because the Plumbers did not have a collective bargaining relationship with Connell and because the subcontracting agreement was not limited to particular job sites, the Court held that the proviso did not apply to the agreement.95

The Court first looked to legislators' statements about the purpose of the proviso in order to determine its scope. The Connell Court found the sparse legislative explanations for the proviso unenliglitening. The legislative history states that the proviso was intended "to preserve the pattern of collective bargaining in the industry," but the

gave in and signed the agreement under protest. Id. at 620. In federal court Connell amended its coinplaint to allege a Sherman Act violation. The union defended on grounds of statutory and nonstatutory exemptions from the antitrust laws, and also claimed that the agreement was privileged by the construction industry proviso to section $8(\mathrm{e})$. The district court, siding with the union, held the agreement to be within the bounds of the proviso and, therefore, beyond the reach of the antitrust laws. Id. at 621 .

In affirming the district court, the Court of Appeals for the Fifth Circuit, 483 F.2d 1154 (5th Cir. 1973), affd in part and rev'd in part, 421 U.S. 618 (1975), took another path. The agreement aimed at a legitimate labor interest: eliminating competition over wages. As a result, the subcontracting restraint enjoyed a nonstatutory labor exemption from the antitrust laws. See $483 \mathrm{~F} .2 \mathrm{~d}$ at 1167-69. The court declined to decide whether the proviso extended to subcontracting agreements made outside of a collective bargaining context, believing that the NLRB had exclusive jurisdiction over labor law questions. Id. at 1167-71, 1175.

92. For a discussion of the antitrust implications of Connell, see St. Antome, supra note 90. See also Casey \& Cozzillio, Labor-Antitrust: The Problems of Connell and a Remedy That Follows Naturally, 1980 DuKE L.J. 235.

93. Four justices dissented, arguing that if the Plumbers' agreement fell outside the protection of the proviso, the labor laws provided an exclusive remedy. The dissenters did not reach the section 8(e) proviso issue. See 421 U.S. at 638 (Douglas, J., dissenting); id. (Stewart, J., joined by Douglas, Brennan, and Marshall, J.J., dissenting).

94. Id. at 633 (majority opinion). The Denver Building Trades problem refers to union picketing at a multi-employer construction site to remove a nonunion subcontractor. See notes 29-38 supra and accompanying text. See also Comment, Hot Cargo Agreements in the Construction Industry: The Effect of Acco Equipment, 15 B.C. INDUS. \& CoM. L. REv. 1292, 1298-99 (1974).

95. 421 U.S. at 633. The Court also held that the Plumbers could not avail themselves of either statutory or nonstatutory exemptions from the antitrust laws. Because neither the labor laws nor the labor exemptions from the antitrust laws provided a defense, the Court held that the Plumbers were not immune froin suit under the Sherman Act. Id. at 635. Counell filed an antitrust suit, rather than charges with the NLRB, because the Board at that time considered subcontracting agreements like the one the Plumbers presented to be valid under section $8(e)$. Sce note 15 supra and accompanying text. 
Connell Court dismissed these remarks as "bare references."96 Even if construction unions had formerly employed top-down organizing, the Court found it unlikely that Congress intended to foster such activity in light of the Landrum-Griffin Act's aim of limiting top-down organizing. 97

Instead, the Court viewed the construction industry proviso as "a partial substitute for an attempt to overrule" the Denver Building Trades decision. ${ }^{98}$ The Conference Committee had added the construction industry proviso to section 8 (e) but had failed to add a provision that would overrule Denver Building Trades and thereby permit common-situs picketing. ${ }^{99}$ The Connell Court considered the commonsitus picketing issue and the subcontracting agreement issue to be interrelated; it therefore read congressional discussion of the common-situs problem as relevant to the secondary agreement issue. ${ }^{100}$ In the Court's view, both subcontracting agreements and common-situs picketing aim at avoiding the simultaneous presence of union and nonunion workers on the same job site. The construction industry proviso was designed to meet this aim, not to permit top-down organizing.

The Court buttressed this analysis by examining the interplay of the two provisos to section $8(e)$. The construction industry proviso does not permit construction unions to enforce subcontracting agreements by strikes and picketing. ${ }^{101}$ This limitation contrasts with the broad freedom to organize given to garment industry unions, which can enforce their subcontracting agreements through economic action. ${ }^{102}$ The

96. 421 U.S. at 628.

97. Id. at 632 .

98. Id. at 629. See note 94 supra. Denver Building Trades had held that union picketing at a construction site for the purpose of removing a nonunion subcontractor was unlawful. See notes 29-38 supra and accompanying text.

99. See 105 CONG. REC. 16,263, 16,416-18 (1951), reprinted in II LEGIS. HIST., supra note 4, at 1396-97, 1434-36. Senator John Kennedy attempted to add such a provision but House members indicated that they would protest this action because it was a new matter that had not previously been considered by either house of Congress. Id .

100. 421 U.S. at 629. The Court noted that

[d]iscussion of "special problems" in the construction industry, applicable to both the section 8(e) proviso and the attempt to override Denver Building Trades, focused on the problems of picketing a single nonunion subcontractor on a multiemployer building project, and the close relationship between contractors and subcontractors at the job site. Id. at 629-30.

101. The construction industry proviso does not exempt construction unions froin section 8(b)(4)(B), which prohibits secondary strikes and boycotts. 29 U.S.C. \& 158(e) (1976). Moreover, Congress specifically stated that secondary subcontracting agreements in the construction industry were not enforceable through economic action. See Conf. Comm. Rep., supra note 64, at 39, reprinted in I LEGIS. HIST., supra note 4, at 943; 105 CoNG. REC. 16,415 (1959), reprinted in II LEGIS. HisT., supra note 4, at 1433.

102. The garment industry proviso, 29 U.S.C. $§ 158(e)(1976)$, permits garment unions both to make and to enforce secondary agreements. See II LEGIS. HIST., supra note 4, at 1377, 1385, 1576, 
comparison between the construction and garment industry provisos suggested to the Court that Congress did not intend the construction industry proviso to shelter agreements designed to organize from the top down. ${ }^{103}$

Finally, the Court noted that the 1959 amendinents reinforced the policy against top-down organizing by establishing "careful limits on the economic pressure unions inay use in aid of the organizational campaigns." 104 The Court found it inconsistent with this general scheme to suggest that Congress intended to give construction unions an unrestricted right to engage in secondary organizational activity. Congress did give special consideration to the construction industry in section 8(f), which authorizes prehire agreenents. ${ }^{105}$ Section $8(\mathrm{f})$ permits an employer to recognize a union before the union has attained majority status, even before the einployees have been hired. These

1708, for discussion of the reasons behind the garment industry excmption. The garment industry was characterized by jobbers who contracted garment work out to small shops. These shops were "fiercely competitive, constantly changing and difficult to organize." Id. 1385 (remarks of Sen. Javits). Sweatshop conditions thus prevailed. Because secondary subcontracting agreements had relieved these conditions, Congress wanted to preserve their lawfulness. See also Danielson v. Joint Bd. of Coat Workers, 494 F.2d 1230 (2d Cir. 1974) (a garment union may lawfully impose an agreement on a jobber not to contract out to nonunion shops, even if the union and the jobber had no collective bargaining agreement).

103. 421 U.S. at 632.

104. Id. at 633. The limits on organizational pressure sought to shield both employer and employee from an undesired union. See id. at 632 n.11. Congress limited secondary pressure by enacting section 8(b)(7), 29 U.S.C. § 158(b)(7) (1976), "which restricts primary recognitional picketing," and by tightening section 8(b)(4)(B), 29 U.S.C. \& 158(b)(4)(B) (1976), "which prohibits the use of most secondary tactics in organizational campaigns." 421 U.S. at 632.

105. 421 U.S. at 633 . Section $8(f)$ provides:

It shall not be an unfair labor practice under subsections (a) and (b) of this section for an einployer engaged primarily in the building and construction industry to make an agreement covering employees engaged (or who, upon their employinent, will be engaged) in the building and construction industry with a labor organization of which building and construction employees are members (not established, maintained, or assisted by any action defined in subsection (a) of this section as an unfair labor practice) because (1) the majority status of such labor organization has not been established under the provisions of section 159 of this title prior to the making of such agreement, or (2) such agreement requires as a condition of employment, membership in such labor organization after the seventh day following the beginning of such einployment or the effective date of the agreement, whichever is later, or (3) such agreement requires the employer to notify such labor organization of opportunities for employment with such employer, or gives such labor organization an opportunity to refer qualified applicants for such employment, or (4) such agreement specifies minimum training or experience qualifications for einployment or provides for priority in opportunities for employinent based upon length of service with such employer, in the indnstry or in the particular geographical area: Provided, That nothing in this subsection shall set aside the final proviso to subsection (a)(3) of this section: Provided further, That any agreement wlich would be invalid, but for clause (1) of this subsection, shall not be a bar to a petition filed pursuant to section 159(c) or 159(e) of this title.

29 U.S.C. $\$ 158(f)$ (1976). The Supreme Court has held that a union may not enforce an 8(f) bargaining relationship until the umon achieves majority support in the bargaining unit. NLRB v. Local 103, Iron Workers, 434 U.S. 335 (1978). 
agreements, however, may be challenged in a representation election ${ }^{106}$ to preserve the employees' right to choose or decline representation. Hence, section 8(f) affords only limited organizing leverage to construction unions.

The Connell Court therefore concluded that to uphold a subcontracting agreement that was obtained outside of a collective bargaining context and was not narrowly directed to the common-situs problein would undermine the anti-secondary provisions of the labor laws and the right of employees to choose a representative freely. ${ }^{107}$

\section{B. Connell Reexamined.}

1. The Tension Between Connell's Analysis and the Language of its Holding. The language of Connell's holding conflicts with the Court's view of the proviso's purpose. Connell indicated that either of two conditions might have brought the Plumbers' subcontracting agreeinent within the ambit of the proviso: a collective bargaining context or a restriction to particular job sites. ${ }^{108}$ Yet earher in the opmion the Court analyzed the proviso as a ineasure to authorize secondary agreements pertaining to the construction site because of the "close commumity of interests" there, or for the "even narrower function" of avoiding job-site friction. ${ }^{109}$ The Court also linked the proviso to efforts to re-

106. See 29 U.S.C. $\$ 159$ (c) (1976).

107. 421 U.S. at 631-33.

108. The Court stated these two conditions both in defining the scope of the construction industry proviso, 421 U.S. at 633, and in announcing the holding of the case, $i d$. at 635 . Professor St. Antoine has suggested that these conditions constitute two logically alternative tests for the validity of a subcontracting clause; however, "the Connell opinion is not clear on these points." St. Antoine, supra note 90, at 619 n.74. Peter Nash, the Board's General Counsel when Connell was decided, recently expressed the view that both conditions inust be inet in order for an agreement to satisfy the construction industry proviso. See Nash, supra note 2, at 674. For the same opinion, see Pacific Northwest Chapter of the Associated Builders and Contractors, Inc. v. NLRB, 609 F.2d 1341 (9th Cir. 1979), petition for rehearing en banc granted, No. 78-3469 (9th Cir. Aug. 19, 1980).

A close reading of Connell, however, refutes Nash's view. The language of the holding inphes alternative conditions. See text accompanying note 94 supra. Furthermore, if the proviso aims only at avoiding job-site friction, as Nash argues, the dual restriction runs counter to Congress's intent. For instance, the einployees of a union subcontractor on a job site have the same interest in seeing that the general contractor does not subcontract to nonunion firms as do the general contractor's own einployees. Under Nash's view, however, unions representing the subcontractor's employees could not sign a subcontracting agreeinent with the general contractor because the subcoutractor's einployees have no collective bargaining relationship with the general contractor. Here, the bargaining relationship requirement serves no purpose but to frustrate unions in their effort to secure an all-union job site.

109. 421 U.S. at 630-31. The court quoted National Woodwork Mfrs. Ass'n v. NLRB, 386 U.S. 612, 638-39 (1967), for the "close community of interests" language. The "even narrower function" had been expressed in Drivers Local 695 v. NLRB, 361 F.2d 547, 553 (D.C. Cir. 1966). Although the Court described the policy of avoiding job-site friction as narrower than the policy 
verse Denver Building Trades, thus implying that the proviso extended only to common-situs agreements. ${ }^{110}$ If the proviso's purpose is to protect agreements that prevent common-situs friction, a valid subcontracting agreement must be restricted to particular sites where union members are working; the presence or absence of a collective bargaming agreement should be irrelevant. The Court failed, however, to address this problem.

2. The Purpose of the Construction Industry Proviso. If Connell's interpretation of the proviso as a measure to relieve job-site conflict is correct, the language of the holding sweeps too broadly. But the Court's interpretation is open to question. First, the cases that Connell rehed on to explain the proviso had addressed different issues than the one facing the Connell Court."11 Second, the legislative history of the proviso establishes that Congress sought to preserve a pattern of bargaming as well as to reduce job-site friction. ${ }^{112}$ Finally, the meaning of job-site friction, which Connell did not explore, has less to do with actual conflict between umion and nonuinon workers at the job site than with the desire of unions to prevent the erosion of union standards and the loss of union jobs. ${ }^{113}$

(a) The cases cited by the Connell Court. In presentimg its view of the proviso's purpose, the Court relied on earlier cases that interpreted the construction industry proviso. The Court quoted the view expressed in National Woodwork Manufacturers Association $v$. $N L R B$ "14 that the proviso recognized the "close community of interests" on a construction site. 115 The Connell Court also noted that "[o]ther courts have suggested that [the proviso] serves an even narrower function . . . to alleviate the frictions that may arise when union men work contmuously alongside nonunion men on the same construction site." "116 This language is drawn from Drivers Local $695 \mathrm{v}$. $N L R B .{ }^{117}$ In contrast to Connell, neither Drivers Local 695 nor $\mathrm{Na}$ tional Woodwork Manufacturers involved subcontractimg restrictions.

of protecting the close community of interests at the job site, it did not explain the difference between the two policies. The authorities that National Woodwork Manufacturers relied on indicate that the two policies are the same. See notes 87-88 supra and accoinpanying text.

110. See notes $98-100$ supra and accoinpanying text.

111. See notes 114-18 infra and accompanying text.

112. See notes 119-25 infra and accompanying text.

113. See notes 132-39 infra and accompanying text.

114. 386 U.S. 612 (1967).

115. 421 U.S. at 630 (quoting 386 U.S. at 639).

116. Id. (quoting Drivers Local 695 v. NLRB, 361 F.2d 547, 553 (D.C. Cir. 1966)).

117. 361 F.2d 547, 553 (D.C. Cir. 1966). 
National Woodwork Manufacturers dealt with work-preservation agreements, and Drivers Local 695 with the meaning of work on a job site. ${ }^{118}$ Also unlike Connell, in both cases the union and the employer did have a collective bargaining agreement. Hence, the earlier decisions did not interpret the purpose of the proviso with respect to subcontracting clauses outside a collective bargaining context.

(b) The legislative history of the proviso and the unique features of the construction industry. The Connell Court's reading of the legislative history overemphasized the common-situs problem as a factor in the enactment of the proviso and underemphasized Congress's desire to preserve construction industry bargaining patterns. Connell cites several passages of the legislative history that discuss the colninon-situs problem in connection with proposals to exempt the construction industry from section 8(e). ${ }^{119}$ The Court interpreted the passages to mean that a common impulse lay behind the construction industry proviso and the proposal to overrule Denver Building Trades. ${ }^{120}$ It therefore termed the proviso "a partial substitute for the attempt to overrule" that case. ${ }^{121}$

Two distimct concerns, however, lay behind the special consideration Congress gave to the construction industry in partially exempting it from section 8(e). On the one hand, the prohibition against coininon-

118. National Woodwork Manufacturers concerned primary activity unrelated to organizational aims. 386 U.S. at 615. See notes 80-84 supra and accompanying text. Drivers Local 695 focused on the distinction between ready-mix concrete deliverers and on-site workers. $361 \mathrm{~F} .2 \mathrm{~d}$ at 552-53. $C$. Acco Constr. Equip., Inc. v. NLRB, 511 F.2d 848, 851 (9th Cir. 1975) (repairmen are not equivalent to on-site workers).

An additional weakness of these authorities is their failure to consult the legislative history of the construction industry proviso for guidance. Both National Woodwork Manufacturers and Drivers Local 695 rely solely on Essex County \& Vicinity Dist. Council v. NLRB, 332 F.2d 636 (3d Cir. 1964), to support their imterpretation of the proviso. Essex County, however, concerned economic pressnre to obtain a concededly valid proviso agreenent. In addition, the Essex County opimion cites no snpport from the Board, the courts, or the legislative history for its view of the proviso. Hence, althongh apparently basing its analysis of the proviso's purpose on solid precedent, the Connell Conrt in fact rehed on the unsnpported dicta of prior cases. Moreover, a case that found a different pnrpose for the section 8(e) proviso-the preservation of "the status quo of bargaining in the construction industry"-received no mention at all. See Dallas Bldg. \& Constr. Trades Council v. NLRB, 396 F.2d 677, 682 (D.C. Cir. 1968).

119. 421 U.S. at 630 n.9.

120. Id. at 629 n.8. The Court stated: "The Conference Committee proposed to include a [Denver Building Trades] amendment to $\S 8(\mathrm{~b})(4)(B)$ in the Conference agreement, along with a closely linked coustruction industry exemption froin $\$ 8(\mathrm{e})$. . . . Bnt a parliainentary obstacle killed the $\S 8(\mathrm{~b})(4)(B)$ amendment, and only the section $8(\mathrm{e})$ proviso survived." 421 U.S. at 629 n.8. See note 99 supra.

121. 421 U.S. at 629. 
situs picketing inspired legislation to permit such picketing. ${ }^{122}$ On the other hand, concern for the independent bargaining patterns in the construction industry elicited proposals to preserve these established patterns. Section $8(f),{ }^{123}$ permitting prehire agreements, was enacted at the same time as the proviso and shows the legislative recognition of the unique patterns of bargaining in the industry. The legislative history thus indicates that the Denver Building Trades problem was not the sole impetus behind section $8(\mathrm{e})$. The unique bargaining patterns in the construction industry were also on the legislators' ininds.

Meinbers of both houses of Congress repeatedly asserted that the proviso to section 8(e) was imtended to preserve the current scheme of union-employer relations im the construction industry. Senator John Keumedy's Conference Report to the Senate stated that the proviso "is intended to preserve the present state of the law . . . . Agreements by which a contractor in the construction industry promises not to subcontract work on a construction site to a nonunion contractor appear to be legal today. They will not be unlawful under section 8(e)."124 The House Conference Report agreed. ${ }^{125}$ Connell thus neglected to recognize that an important purpose of the proviso was to adjust the labor laws to the special needs of construction unions, including their estabhished bargaining patterns.

The construction industry has several unique features ${ }^{126}$ that underlie section $8(f)$ and the proviso to section $8(e)$. First, construction work lasts only a limited time at a single site. ${ }^{127}$ Employees are therefore constantly changing employers and moving to new job sites. To represent those workers effectively, unions inust be able to bargain with employers on their behalf even before the workers are hired for a specific job. ${ }^{128}$ Second, to make an accurate bid, the employer needs to know his labor costs before a job begins. Moreover, he must have quick access to a pool of workers once the job starts. ${ }^{129}$ Third, subcon-

122. The various bills that included proposals to overrule the ban on common-situs picketing are listed in II LEGIS. HisT., supra note 4, at 1912-15.

123. 29 U.S.C. $\$ 158(f)(1976)$.

124. 105 CONG. REC. 17,900 (1959), reprinted in II LEGIS. HIST., supra note 4, at 1433.

125. See Conf. CoMm. ReP., supra note 44, at 39 (1959), reprinted in I LEGIs. Hist., supra note 4 , at 943.

126. See S. REP. No. 187, 86th Cong., 1st Sess. 27 (1959), reprinted in I LEGIS. Hist., supra note 4 , at 423.

127. Id. See also Fleming, supra note 28, at 1033.

128. This is the type of agreement permitted by section $8(f)$ of the Landrum-Grifin Act, 29 U.S.C. § 158(f) (1976).

129. For these reasons, prehire agreements were prevalent in the construction industry even after the Taft-Hartley Act brought construction workers under the Board's jurisdiction. For evidence of congressional awareness of these features, see S. REP. No. 187, supra note 126, at 28 , 
tracting is the norm rather than the exception in the industry. The general contractor typically employs many subcontracting firms on the job site. ${ }^{130}$

The labor laws, designed to promote fair labor practices in manufacturing, did not originally take into account these unique features of construction labor. ${ }^{131}$ The requirement that a union obtain majority support after the employees have been hired, though appropriate in the manufacturing context, did not fit the construction industry. Similarly, though the condemnation of hot-cargo contracts shielded neutral employers in most lines of work, in the construction industry it denied to unions a tool to ensure that union members would be employed on the construction site even if the general contractor subcontracted the work sought by the union. Congress passed section $8(f)$ and the proviso to section $8(\mathrm{e})$ to make the necessary adjustments.

(c) The meaning of "job-site friction." Connell suggested that a recognition of union soldarity at the job site or the narrower intention to permit the avoidance of job-site friction caused Congress to adopt the construction industry proviso. ${ }^{132}$ The Court did not shed much hight on the source of either the solidarity or the friction. Drivers Local 695 v. $N L R B,{ }^{133}$ cited by the Court, ${ }^{134}$ seeins to view the friction as stemming from hostility between union and nonunion workers. ${ }^{135}$ The legislative history, however, implies that Congress was concerned that nonunion firms on a project would impair the benefits for workers that unions had won. Read in light of the legislative history, both the "close community of interests" language and the reference to avoiding job-site friction point to a simgle phenomenon: the solidarity of union meinbers in refusimg to work with nonunion workers because to tolerate nonumon firms on the job site would undermine the union's strength.

reprinted in I LEGIS. HIST., supra note 4, at 424. Section 8(e) proviso agreements were also used in the construction industry to further the aim of establishing union conditions on job sites. Congress, in passing the proviso, recognized that the proviso was "necessary to avoid serious damage to the pattern of collective bargaining . . . ." 105 CONG. REC. 17,899 (1959), reprinted in II LEGIS. Hist., supra note 4, at 1432.

130. See Comment, supra note 94, at 1297.

131. See note 28 supra.

132. 421 U.S. at $630-31$.

133. 361 F.2d 547 (D.C. Cir. 1966).

134. See 421 U.S. at 630.

135. The Drivers Local 695 court stressed that the friction occurs between union and nonunion workers who come into contact "continuously" on a construction site. 361 F.2d at 553. The facts of NLRB v. Denver Bldg. \& Constr. Trades Council, 341 U.S. 675 (1951), however, suggest that union workers may not know or be concerned about the presence of nonunion workers on the site until the union officials make thein aware. See id. at 679 (the Trades Council picketed the site of construction "to notify their members that nonunion men were working on it"). 
Twice during the Senate debate on the proposed amendments to Taft-Hartley, Senators recited the facts of Denver Building Trades ${ }^{136}$ to argue that Congress should legislatively overrule the case. Senator Morse emphasized that the union workers in Denver Building Trades refused to tolerate a nonunion subcontractor on the site because the nonunion subcontractor paid forty-two cents an hour less than was paid to union workers. ${ }^{137}$ Senator Carroll repeated this fact, adding that "[t]he building trades workers-carpenters, bricklayers, and the rest-said 'we refuse to work alongside them." "138

These interpretations of Denver Building Trades emphasize that the protest of union workers against working with nonunion workers grows out of their concern that the subcontracting of work to nonunion firms will erode negotiated union standards. To permit a general contractor to subcontract to nonunion firms is to allow him to evade his collective bargaining obligations. This concern extends not only to job sites at which the general contractor brings a nonunion subcontractor together witl his own union workers, but also to job sites at which the general contractor displaces his union einployees by subcontracting all the work to nonunion firms. ${ }^{139}$

In sund, the Connell Court's holding gave a broader scope to the proviso than its analysis of the proviso's purpose suggested was appropriate. Moreover, the Court, im stating the purpose of the proviso, failed to accord sufficient weight to Congress's desire to preserve bargaining patterns, and thus overemphasized the problem of job-site friction. Finally, although the Court did not discuss what it meant by jobsite friction, it appeared to endorse the view that such frictions exist between union and nonunion workers. In fact, however, the source of the tension is the general contractor who mvites the nonunion subcontractor onto the site.

The Connell decision forced the National Labor Relations Board and the courts to choose between incoinpatible alternatives. If a collective bargaining relationship protects a subcontracting agreeinent, as the holding implies, a union may impose an agreeinent on employers even

136. 341 U.S. 675 (1951). See notes 29-38 supra and accompanying text.

137. 105 CONG. REC. 16,396 (1959), reprinted in II LEGIs. HIST., supra note 4, at 1425. See note 36 supra.

138. 105 CoNG. REC. 16,418 (1959), reprinted in II LEGIS. HIST., supra note 4, at 1436.

139. Denver Building Trades involved only a common-situs conflict. See 186 F.2d at 332 (Trades Council einployees of the general contractor at other job sites remained on the job), rev'd, 341 U.S. 675 (1951). The court in In re Bullard Contracting Co., 464 F. Supp. 312 (W.D.N.Y. 1979), however, recognized that the job-site conflict might occur precisely when the general contractor subcontracted all job-site work. Id. at 317 . See also notes 152-54 infra and accompanying text. 
though the agreement is not restricted to a particular job site. But if the proviso shelters only those agreements aimed at common-situs problems, the restriction to a particular job site is crucial. This uncertainty guaranteed controversy im applying Connell to different factual settimgs.

\section{The Response of the Board's General Counsel and the Courts to Connell.}

1. The NLRB General Counsel's Connell Memorandum. The General Counsel's reaction to the Connell decision demonstrated that the ambiguities of the opinion offered a springboard for a narrow reading of the construction industry proviso. A nemo froin the General Counsel, issued in December 1976, fixed policy on when to issue complaints attacking subcontracting clauses under section 8(e) in light of Connell. ${ }^{140}$ According to the General Counsel, Connell requires the conclusion that the "proviso reflected a Congressional determination that a construction union has a legitimate interest in assuring that employees represented by it on a construction site are not required to work alongside non-union employees on that site"; 141 any subcontractimg agreement broader than necessary to further this interest would not fit under the proviso.

The inemorandum asserted that under Connell a subcontracting agreement is lawful only if entered into in the context of collective bargaining. ${ }^{142}$ But to accord with its conception of the proviso's purpose, the meinorandun further required that subcontracting restrictions operate only at particular job sites and only at tinies when union employ-

140. NLRB General Counsel's Memorandum, supra note 14, at I, reprinted in LAB. REL. YEARBOOK 295 (1976). The General Counsel's memorandum provides guidance on how regional offices should handle subcontracting agreements under Connell. The regional offices have the responsibility to issue complaints upon charges filed by an aggrieved party. Id I-II, reprinted in LAB. ReL. YeARBOOK 296 (1976).

141. Id. II, reprinted in LAB. ReL. Yearbook 296 (1976). Under section 3(d) of the Act, 29 U.S.C. § 153(d) (1976), the General Counsel has a responsibility to authorize the issuance of a complaint if reasonable cause exists to believe that a given practice violates the Act. In light of the unpredictable development of the law under section 8(e), the General Counsel found it necessary to consider post-Connell issues carefully and to resolve doubts by issuing complaints in order to allow the Board and courts to adjudicate the issues. NLRB General Counsel's Memorandum, supra note 14, at VII, reprinted in LAB. REL. YEARBOOK 300 (1976).

142. NLRB General Counsel's Memorandum, supra note 14, at 4, reprinted in LAB. REL. YEARBOOK 297-98 (1976). The memorandum suggested, however, that a union representing a subcontractor's employees might lawfully agree with the general contractor to confine job-site subcontracting to union firms even in the absence of a collective bargaining agreement. Id., reprinted in LAB. REL. YEARBOOK 298 (1976). The common-situs relationship would be enough to place such a clause within the purpose that Connell assigned to the proviso. 
ees would be present. 143 These additional limitations nullify the language of the Connell holding, which indicated that a collective bargaining relationship alone is enough to bring a subcontracting agreeinent within the proviso. ${ }^{144}$

The memorandum also stated that a regional office should issue a complaint when a subcontracting clause restricts subcontracting to firms having a bargaining relationship with a specified union rather than with any union. ${ }^{145}$ While noting that Senator Kennedy believed the construction industry proviso was "necessary to avoid serious dainage to the pattern of collective bargaining" in the industry, 146 the General Counsel weighed these remarks against the fact that unionsignatory subcontracting clauses lend theinselves to top-down organizing, ${ }^{147}$ which Connell had condemned. In addition, the General Counsel questioned whether the pattern of collective bargaining in the construction industry in 1959 included union-signatory clauses. To determine what bargaining patterns existed in 1959, the General Counsel examined studies of that year's bargaining agreements and initiated his own study. ${ }^{148}$ The evidence gathered by the General Counsel suggested that subcontracting agreements varied widely in 1959. He there-

143. Id. 20, reprinted in LAB. REL. YeARBOoK 312-13 (1976). These limitations ensure that a subcontracting agreement will protect against shoulder-to-shoulder job-site friction, but will not become an instrument for top-down organizing.

The memorandum also determined that a section $8(f)$ agreement is a sufficient collective bargaining relationship under Connell, with certain limitations. First, the clause must not be operational before employees are hired, because at that point no employees that the union represents are threatened by the prospect of working on a job site along with nonunion employecs. Second, the operation of the clause must be restricted to times when the represented employees will actually be at work. The General Counsel further contended that subcontracting restrictions on craft union members performing work outside the jurisdiction of the bargaining unit were permissible, because union carpenters have the same interest in working alongside union plunbers and electricians as they do in working with union carpenters. Id. 8-9, reprinted in LAB. REL. YEARBOoK 305 (1976).

144. See note 108 supra and accompanying text.

145. NLRB General Counsel's Memorandun, supra note 14, at V-VI, reprinted in LAB. REL. YEARBOOK 298-99 (1976).

146. Id. 13, reprinted in LAB. ReL. YeARBOoK 308 (1976) (quoting 105 CONG. REC. 17,899 (1976), reprinted in II LEGIS. HIST., supra note 4, at 1432).

147. See note 10 supra.

148. NLRB General Counsel's Memorandum, supra note 14, at 13-16, reprinted in LAB. ReL. YEARBOOK 308-09 (1976). The General Counsel reviewed Lunden, Subcontracting Clauses in Major Contracts, 84 MoNTHLY LAB. REv. 579-86, 715-23 (1961). The General Counsel's own study evaluated contracts on file at the Department of Labor, and contracts provided by the AFL-CIO. NLRB General Counsel's Memorandum, supra note 14, at 14, reprinted in LAB. REL. YEARBOoK 309 (1976). 
fore concluded that Congress could not have intended to preserve this "mosaic."149

By concentrating on the purposes Connell attributed to the proviso, the General Counsel's meinorandum read out of the Connell opinion the "context of a collective bargaining relationship" language that was central to the Court's holding. Furthermore, the General Counsel accepted the job-site friction rationale as the only purpose behind the proviso. By jettisoning continuity of bargaining patterns as a congressional motive, the General Counsel endorsed Connell's narrow view of the proviso.

2. Court Decisions Interpreting Connell. The district courts considering Connell's innpact divided into two groups. One group emphasized the iniportance of the presence or absence of a collective bargaining relationship in deciding whether the proviso protects a subcontracting clause. ${ }^{150}$ The other group stressed the avoidance of jobsite conflict as the determining factor. ${ }^{151}$

In Orange Belt Council v. Maloney, Inc., ${ }^{152}$ the einployer challenged the validity of a union-signatory subcontracting agreeinent ${ }^{153}$ that was not restricted to particular job sites. In upholding the clause, the court distinguished Connell on the ground that the union in Connell did not represent Connell's employees, but the union in the case at bar did represent Maloney's employees. ${ }^{154}$ In contrast, Operating Engineers

149. NLRB General Counsel's Memorandum, supra note 14, at 16, reprinted in LAB. REL. YEARBOOK 309 (1976).

150. See notes $152-54$ infra and accompanying text.

151. See notes $155-58$ infra and accompanying text.

152. 98 L.R.R.M. 3193 (C.D. Cal. 1978), aff'd on other grounds, 106 L.R.R.M. 2183 (9th Cir. 1980).

153. See note 10 supra.

154. 98 L.R.R.M. at 3194. The court also stated: "I cannot believe that [the employer] effectively could have nullified the proviso by simply making certain that none of his own employees were on the same job site as the subcontractor's non-union people." Id. The court thus implied that to create such a rule would encourage an employer to ignore his collective bargaining agreement with the union and subcontract all work at the job site to nonumion firms.

A similar subcontracting clause in a collective bargaining agreement was upheld against an antitrust attack in In re Bullard Contracting Corp., 464 F. Supp. 312 (W.D.N.Y. 1979). But see Larry V. Muko, Inc. v. Southwestern Pa. Bldg. \& Constr. Trades Council, 609 F.2d 1368, 1375 (3d Cir. 1979) (en banc) (holding an' agreement invalid on antitrust grounds becanse "here there is neither a collective bargaining relationship. . . nor any evidence of a common-situs problem"). The Federal Trade Commission has also attacked subcontracting agreements on antitrust grounds. See In re Teamsters Local 959, 93 F.T.C. 739 (1979) (the Teamsters signed a consent decree agreeing not to enter into subcontracting agreements that extended beyond particular job sites); Report on Federal Trade Commission Action against the Alaska Teamsters, 138 DAlLY LAB. REP. (BNA) A-1 (July 18, 1978).

For an antitrust counterattack by the construction unions, see California State Council of Carpenters v. Associated Gen. Contractors of Cal., Inc., No. 77-2323 (9th Cir. Nov. 20, 1980) (the umions' allegation that construction employers had conspired to boycott union subcontracting firms was held to state a Sherman Act claim). 
v. Neilsen \& Co. ${ }^{155}$ held a subcontracting agreement unlawful on antitrust grounds after rejecting a construction-industry proviso defense. ${ }^{156}$ The court reasoned that the proviso was designed only to eliminate jobsite friction. Because no union employees were present on the site, the agreement did not serve this purpose and therefore was void. ${ }^{157}$ Similarly, in Long v. Floorcraft Carpet Co. ${ }^{158}$ the court refused to enforce a subcontracting agreeinent that operated when union employees were not present at the site with the subcontractor's nonunion employees.

\section{The Board's Post-Connell Decisions.}

The Board addressed the post-Connell issues in four cases joined for argument in 1978. 159 These cases required the Board to clarify the import of the Connell decision for secondary subcontracting agreements. The Board, limiting Connell to its facts, upheld broad subcontracting restrictions within a collective bargaining context and decided that a prehire agreement under section 8(f) satisfied the collective bargaining requirement.

In Carpenters Local 944 (Woelke \& Romero Framing, Inc.) ( $^{160}$ a subcontractor and a carpenters local, while renegotiating a collective bargaining agreement, reached an inpasse over whether to retain a union-signatory subcontractimg clause in the new contract. 161 The union then picketed four job sites, stopping work at two of then.

155. 92 L.R.R.M. 2861 (D. Idaho 1975).

156. The court found that the agreement violated the Sherman Act and that the construction indnstry proviso did not shield it. Id. at 2863-64.

157. Id.

158. 95 L.R.R.M. 3143 (D. Or. 1977).

159. Carpenters Local 944 (Woelke \& Romero Framing, Inc.), 239 N.L.R.B. 241 (1978), enforced as modified sub nom. Pacific Northwest Chapter of the Associated Builders \& Contractors, Inc., v. NLRB, 609 F.2d 1341 (9th Cir. 1979), petition for rehearing en banc granted, No. 78-3469 (9th Cir. Aug. 19, 1980); Colorado Bldg. \& Constr. Trades Council (Utilities Servs. Eng'g, Inc.), 239 N.L.R.B. 253 (1978); Los Angeles Bldg. \& Constr. Trades Council (Donald Schriver, Inc.) (Sullivan-Kelley \& Assocs.), 239 N.L.R.B. 264 (1978), enforced sub nom. Donald Schriver, Inc. v. NLRB, 635 F.2d 859 (D.C. Cir. 1980); Operating Eng'rs Local 701 (Pacific Northwest Chapter of the Associated Builders \& Contractors, Inc.), 239 N.L.R.B. 274 (1978), enforced as modified sub nom. Pacific Northwest Chapter of the Associated Builders \& Contractors, Inc. v. NLRB, 609 F.2d 1341 (9th Cir. 1979), petition for rehearing en banc granted, No. 78-3469 (9th Cir. Aug. 19, 1980).

160. 239 N.L.R.B. 241 (1978), enforced as modified sub nom. Pacific Northwest Chapter of the Associated Builders \& Contractors, Inc. v. NLRB, 609 F.2d 1341 (9th Cir. 1979), petition for re. hearing en banc granted, No. 78-3469 (9th Cir. Aug. 19, 1980).

161. 239 N.L.R.B. at 241. The contract also contained an alteruative subcontracting clause that purported to meet the requirements of a valid union-standards clause (for a definition of a union standards clause, see note 10 supra), but the Board found that the terms were so specific that only an affiliate of the Carpenters could qualify; the alternative clause was therefore equivalent to a union-signatory subcontracting clause. 239 N.L.R.B. at 247. 
Woelke filed charges under section $8(\mathrm{~b})(4)(\mathrm{A})$. $^{162}$

The Board first determined that the subcontracting agreenents had secondary purposes ${ }^{163}$ and then held that under Connell the proviso to section 8(e) protects subcontracting agreements in a collective bargaining context regardless of whether they are limited to particular job sites. ${ }^{164}$ According to the Board, the Connell Court's description of the proviso's purposes bore only on agreements outside of a collective bargaining relationship. ${ }^{165}$ Connell thus did not require that the Board disallow a broad subcontracting agreenent negotiated within such a relationship.

In the second case, Operating Engineers Local 701 (Pacific Northwest Chapter of the Associated Builders and Contractors, Inc.), ${ }^{166}$ an engineers' local entered into a collective bargaining agreenent with an association of general contractors. The agreement required all subcontractors to be parties to "an existing labor agreement with the Union."167 The agreeinent also provided that the parties would arbitrate grievances, but that the union could resort to self-help enforcement of the arbitrator's decision. ${ }^{168}$ A second contractors' association alleged that the clause violated section $8(\mathrm{e})$. The Board held that the

162. 29 U.S.C. $\S 158(b)(4)(A)(1976)$. This section prohibits picketing or threatening to picket for the purpose of obtaining an agreement that violates section 8(e). Agreements that are lawful under section $8(\mathrm{e})$, such as those the proviso protects, are exempt from scrutiny under section 8(b)(4)(A). See Building \& Constr. Trades Council v. NLRB, 328 F.2d 540, 542 (D.C. Cir. 1964). Pressure may thus be used to obtain lawful section 8(e) proviso subcontracting agreements, subject to certaim limits. Construction, Prod. \& Maintenance Laborers Local 383 v. NLRB, 323 F.2d 422 (9th Cir. 1963). First, if the aim of the desired agrcement is to force the termination of business relations between the employer and a specific second person, the picketing may violate section 8(b)(4)(B) despite its lawfulness under section 8(b)(4)(A). Sccond, if the union exerting pressure seeks a subcontracting clause in the context of recognitional picketing - that is, if the union seeks not only a subcontracting clause, but agreèments about wages, hours, pensions, grievance procedures, union security, working conditions, and health and safety benefits-the picketing is regulated by section 8(b)(7), 29 U.S.C. § 158(b)(7) (1976). Section 8(b)(7)(A), 29 U.S.C. \& 158(b)(7)(A) (1976), flatly bans recognitional picketing when the employer has recognized another union; section 8(b)(7)(B), 29 U.S.C. \& 158(b)(7)(B) (1976), prohibits all recognitional picketing when a valid election has been held within one year. In all other cases section $8(b)(7)(C)$ prohibits recognitional picketing beyoud a reasonable time not to exceed thirty days unless the union files an election petition with the Board.

163. 239 N.L.R.B. at 247.

164. Id. at 250. The union and the contractor had also reached an impasse over the union's proposal to include foremen in the bargaining unit. The Board found that the union's attempt to include supervisors in the collective bargaining unit was an unfair labor practice under section 8(b)(1)(B), 29 U.S.C. $§ 158(b)(1)(B)(1976)$.

165. 239 N.L.R.B. at 249.

166. 239 N.L.R.B. 274 (1978), enforced as modified sub nom. Pacific Northwest Chapter of the Associated Builders \& Contractors, Inc. v. NLRB, 609 F.2d 1341 (9th Cir. 1979), petition for rehearing en banc granted, No. 78-3469 (9th Cir. Aug. 19, 1980).

167. 239 N.L.R.B. at 275.

168. $I d$. 
self-help enforcement clauses rendered the otherwise lawful subcontracting agreement unlawful. ${ }^{169}$ Although the construction industry proviso protects the subcontracting restraint, section $8(b)(4)(B){ }^{170}$ prohibits its coercive enforcement.

The third of the four decisions, Los Angeles Building and Construction Trades Council (Donald Schriver, Inc.), 171 involved the facts of two cases. In Donald Schriver ${ }^{172}$ an owner-builder, Schriver, had signed an agreement with the Tradcs Council under section 8(f), ${ }^{173}$ which permits recognition of minority unions in the construction industry. At no time, however, had Schriver employed union nembers. The agreement contained both a secondary subcontracting clause and a self-help enforcement clause. The Carpenters, an affiliate of the Trades Council, threatened to picket Schriver to enforce the bargaining agreement, but no picketing actually occurred. Schriver brought unfair labor practice charges against the Carpenters, alleging that the agreement violated section 8(e). In the related case ${ }^{174}$ Topaz, a nonunion framing subcontractor, began work on an all-union site. The Carpenters presented Topaz with the union's standard collective bargaining contract, which contained a union-signatory subcontracting clause with a self-help enforcement provision. Topaz declined to sign a contract that apphed beyond the job site at which he was currently working. The Carpenters then picketed the job site for ten days. Topaz alleged that the picketing violated section $8(\mathrm{~b})(4)(\mathrm{A})$ because the subcontracting clause was illegal under section 8(e).

The Board had decided in Woelke \& Romero that the construction industry proviso sheltered subcontracting clauses like the ones involved in Donald Schriver and Topaz (but for their self-help enforcement provisions) if the clauses were contained in a collective bargaining agreement. ${ }^{175}$ The consolidated Donald Schriver case presented the question whether a section 8(f) prehire agreement satisfied the collective bargaining requirement. The Board held that it did. ${ }^{176}$ Congress had enacted section $8(\mathrm{f})$ and the proviso to section $8(\mathrm{e})$ to harmonize federal labor policy with the economic reality of the construction industry. The Board therefore decided to "coordinate" section 8(f) with the pro-

169. Id. at 278 .

170. 29 U.S.C. $\$ 158($ b)(4)(B) (1976).

171. 239 N.L.R.B. 264 (1978), enforced sub nom. Donald Schriver, Inc. v. NLRB, 635 F.2d 859

(D.C. Cir. 1980).

172. 239 N.L.R.B. at $265-66$.

173. 29 U.S.C. $\$ 158(f)(1976)$. For the text of section $8(f)$, see note 105 supra.

174. 239 N.L.R.B. at 266.

175. See id. at $245-47$.

176. Id. at 270 . 
viso to section 8(e) and to permit a prehire agreement to support a subcontracting restraint. ${ }^{177}$ The Board held invalid the self-help enforceinent clauses, however. ${ }^{178}$

In the fourth case, Colorado Building and Construction Trades Council (Utilities Services Engineering, Inc.), 179 a construction contractor had no collective bargaining agreenent with a union. The Trades Council presented the contractor with a subcontracting proposal, but did not seek to represent the contractor's employees. ${ }^{180}$ Building on the Woelke \& Romero analysis, the Board noted that Connell required either of two conditions before an agreenent would be permitted under the construction industry proviso: a bargaining relationship or a cominon-situs limitation. ${ }^{181}$ Here, there was no bargaining relationship between the Trades Council and the contractor, nor was the agreement designed to avert common-situs tension. The agreement's operation was not limited to times when union workers would work alongside nonunion workers. In addition, the clause permitted union and nonunion workers to be present on the same job site, for it did not restrict the subcontracting of work in trades other than those represented in the Trades Council. The Board thus found that the agreement violated section $8(\mathrm{e}){ }^{182}$

In these four decisions the Board seized on the facts and holding of Connell rather than concentrating on Connell's statement of the proviso's purposes. ${ }^{183}$ Confining Connell's policy analysis to subcontract-

177. Id. The Board found that section $8(f)$ and the construction industry proviso were the product of congressional concern for the unique features of the construction industry, described in text accoinpanying notes 126-30 supra. 239 N.L.R.B. at 269.

178. 239 N.L.R.B. at 270. A lawful construction-industry subcontracting agreeinent cannot be coercively enforced. See note 101 supra. See also Ets-Hokin Corp., 154 N.L.R.B. 839 (1965), enforced sub nom. NLRB v. International Bhd. of Electrical Workers Local 769, 405 F.2d 159 (9th Cir. 1968), cert. denicd, 395 U.S. 921 (1969).

179. 239 N.L.R.B. 253 (1978).

180. Id.

181. 239 N.L.R.B. at 255-56.

182. Id. at 254-55. The agreement that the union sought resembled the Connell agreement itself, and the Board appropriately found it unlawful. The Court of Appeals for the Third Circuit recently decided an antitrust case with facts similar to Connell; the court used reasoning similar to the Board's in Colorado Building Trades. See Larry V. Muko, Inc. v. Southwestern Pa. Bldg. \& Constr. Trades Council, 609 F.2d 1368 (3d Cir. 1979) (en banc).

183. The Board stated in Woelke \& Romero that

the [Connell] Court's entire decision is cast in terms of the impact of the absence of a collective-bargaining relationship upon the applicability of the proviso . .... The bottom line of the Court's opinion, as we construe it, is that the construction industry proviso to Section 8(e) permits subcontracting clauses such as those here in the context of a collective bargaining relationship, and possibly even without such a relationship if the clauses are aimed at avoiding the Denver Building Trades problem.

239 N.L.R.B. at 250. This assessment of Connell closely resembles the language of Connell's holding. See text accompanying note 94 supra. 

considered two Board decisions, Woelke \& Romero Framing ${ }^{190}$ and $O p$ erating Engineers Local 701.191 A panel of the court agreed with the Board that the subcontracting clauses involved in both decisions were secondary, 192 but held that the proviso did not protect the clauses despite the presence of collective bargaining relationships. ${ }^{193}$ The court ruled that a bargaining relationship is not enough; the employer or a subcontractor must also at "soine time"194 have union members work$\mathrm{mg}$ at the job site where the union wishes to restrict subcontractimg. In addition, the restriction may neither extend beyond that site nor include crafts other than that of the signatory union. ${ }^{195}$ The court would, however, permit union-signatory-subcontracting clauses. ${ }^{196}$

The unions in Pacific Northwest argued that when Congress passed section 8(e), union-signatory subcontractimg clauses were lawful under the Supreme Court decision in Local 1976 United Brotherhood of Carpenters v. $N L R B$ (Sand Door). ${ }^{197}$ Reading the legislative history to

190. 239 N.L.R.B. 241 (1978), enforced as modified sub nom. Pacific Northwest Chapter of the Associated Builders \& Contractors, Inc. v. NLRB, 609 F.2d 1341 (9th Cir. 1979), petition for rehearing en banc granted, No. 78-3469 (9th Cir. Aug. 19, 1980).

191. 239 N.L.R.B. 274 (1978), enforced as modified sub nom. Pacific Northwest Chapter of the Associated Builders \& Contractors, Inc. v. NLRB, 609 F.2d 1341 (9th Cir. 1979), petition for rehearing en banc granted, No. 78-3469 (9th Cir. Aug. 19, 1980).

192. 609 F.2d at 1346. The court also agreed with the Board that picketing to include foremen within the bargaining unit violated section 8(b)(1)(B), 29 U.S.C. $\$ 158(\mathrm{~b})(1)(B)(1976)$. 609 F.2d at 1351. See note 164 supra.

193. The Pacific Northwest court did not consider what standard to use when reviewing thc Board's interpretation of the National Labor Relations Act. The Supreine Court has stated, however, that a court should give the Board's interpretation of the Act substantial deference when it is "defensible," even if the court would prefer a different approach. See NLRB v. Local 103, Iron Workers, 434 U.S. 335, 350 (1978). In Local 103 the Court upheld the Board's ruling that picketing to enforce a pre-hire agreement under section $8(\mathrm{f})$ is recognitional picketing regulated by section $8(\mathrm{~b})(7)$ until the union achieves majority status. But the Court recognized that there were other tenable interpretations of the Act. $I d$.

194. $609 \mathrm{~F} .2 \mathrm{~d}$ at 1347. The court held that

the construction industry proviso extends shelter only when a collective bargaining relationship exists and even then only when the employer or his subcontractor has employees who are members of the signatory union at work at soine time at the job site at which Id.

the employer wishes to engage a non-union subcontractor.

195. On the restriction to a particular job site, see id. at 1347-48; on the restriction to the signatory union's crafts, see id. at 1349-50. Although the Pacific Northwest court did not acknowledge this, the craft restriction would prevent a union from overcoming the common-situs tension that arose in NLRB v. Denver Bldg. Constr. Trades Council, 341 U.S. 675 (1951). See text accoinpanying notes 137-38 supra.

196. 609 F.2d at 1350 n.8. It is not clear, however, whether the court would require a subcontracting clause to be a union-signatory clause. See note 10 supra for a discussion of union-signatory clauses.

197. 357 U.S. 93 (1958). The Court of Appeals for the Ninth Circuit phrased the Board's and the union's argument as a syllogism: "At the timc the proviso was enacted, the union signatory subcontractor provisions were lawful. The proviso intended to preserve in the construction indus- 
indicate that Congress intended to preserve the existing law, 198 the unions concluded that such clauses remained lawful. ${ }^{199}$ The Court of Appeals for the Ninth Circuit rejected both premises of this argument. Contrary to the unions' position, the Pacific Northwest court believed that Sand Door held only that a hot-cargo agreeinent was not a defense to a charge under section 8(b)(4) of the Taft-Hartley Act; that the Sand Door Court expressly declined to address the validity of hot-cargo agreements; 200 and that because Sand Door concerned only a product boycott, it did not resolve the lawfulness of subcontracting agreeinents under Taft-Hartley. ${ }^{201}$

These observations do not accord with the Supreme Court's interpretation of Sand Door. In National Woodwork Manufacturers Association v. $N L R B^{202}$ the Court declared that section 8(e) was designed to plug the loophole created when Sand Door ruled that hot-cargo agreements were lawful.203 The Court reaffirmed the view that Sand Door upheld such agreements in NLRB v. Pipefitters Local 638.204 In that case the Court stated that "the inaking and voluntary observance of [hot-cargo] contracts were not contrary to law at the time that Sand Door was decided . . . ."205 Neither of these cases distimguished between secondary product-boycott contracts and secondary subcontracting contracts. Thus, later Supreme Court decisions considered Sand Door to have resolved the legahty of secondary agreements.

Pacific Northwest also rejected the unions' claim that the proviso intended to preserve the existing state of the law, finding the proviso's effect on the law of Sand Door "unclear."206 Although a Conference Report to the House ${ }^{207}$ and statements of Senator Jolin Keimedy ${ }^{208}$ suggest that section 8(e) and the proviso preserve the law of Sand Door, the Pacific Northwest court found these statements unreliable. The court beheved that the Act changed the law of Sand Door: although

try the law as it then existed. Hence, the proviso was intended, and should be construed, to protect subcontractor provisions." 609 F.2d at 1348.

198. 609 F.2d at $1348-49$.

199. Id.

200. Id. at 1349 .

201. Id. at 1348. A product-boycott agreement obligates an employer not to require his einployees to use goods made by nonunion workers. A subcontracting agreement obligates an employer not to subcontract to nonunion firms.

202. 386 U.S. 612 (1967).

203. Id. at 634 .

204. 429 U.S. 507 (1977).

205. Id. at 516 .

206. 609 F.2d at 1349.

207. Conf. CoMm. ReP., supra note 64, at 39, reprinted in I LEGIS. HisT., supra note 4, at 934, 943.

208. 105 CONG. REC. 16,415 (1959), reprinted in II LEGIS. Hist., supra note 4, at 1433. 
Sand Door did not restrict lawful secondary agreements to the job site, section 8(e) contains a job-site restriction. ${ }^{209}$

The Pacific Northwest court then independently inquired into the proviso's purpose. ${ }^{210}$ Relying on a pre-Connell Ninth Circuit case, ${ }^{211}$ the court construed the purpose to be "minimizing job site tension."212 The agreements at issue in Pacific Northwest operated even when no union workers were on the job; the agreements therefore exceeded the purpose of the proviso. The court added that its holding preserved the section $7^{213}$ rights of workers to engage in or refrain from union activity. ${ }^{214}$ In order to protect those rights, the court found it necessary to restrict the top-down organizing potential of subcontracting agreements. 215

\section{B. The District of Columbia Circuit's Adoption of the Board's View of the Proviso.}

In Donald Schriver, Inc. v. $N L R B, 216$ the Court of Appeals for the District of Columbia Circuit enforced the NLRB's decision in Los Angeles Building and Construction Trades Council (Donald Schriver, Inc.). ${ }^{217}$ The court held that a section 8(f) agreement comphes with Connell's collective bargaining test, 218 that a subcontracting agreement may extend beyond a job site where union members are currently working, ${ }^{219}$ and that the agreement may specify a particular union. ${ }^{220}$

The Donald Schriver court distimguished Connell by noting the total absence of a collective bargaining relationship in that case.221 Connell held that a collective bargaining relationship is necessary to trigger the protection of the construction industry proviso;222 it did not, however, specify what type of relationship would suffice. Donald Schriver

209. 609 F.2d at 1348.

210. Id. at 1349.

211. Acco Constr. Equip., Inc. v. NLRB, 511 F.2d 848 (9th Cir. 1975) (denying protection under the proviso to a subcontracting clause that covered on-site equipinent repairmen).

212. 609 F.2d at 1349.

213. 29 U.S.C. $\$ 157$ (1976). For the text of section 7, see note 56 supra.

214. $609 \mathrm{~F} .2 \mathrm{~d}$ at 1349.

215. Id. at 1350 .

216. 635 F.2d 859 (D.C. Cir. 1980).

217. 239 N.L.R.B. 264 (1978).

218. $635 \mathrm{~F} .2 \mathrm{~d}$ at 875 .

219. Id. at 881 .

220. Id. at 884-85.

221. Id. at 873 .

222. 421 U.S. at 633. The Court also left room for a narrow common-situs agreement that would not have to be negotiated in a collective bargaining context. Id. No court has yet upheld a subcontracting agreement of this nature. 
declared that a prehire agreement is sufficient. ${ }^{223}$ Not only are prehire agreements the standard form of agreement in the construction industry, ${ }^{224}$ but their presence alters the function of the subcontractimg agreement itself. In Connell the subcontracting agreements had a purely secondary organizational impact;"225 in Donald Schriver " $[t]$ heir primary goal was not to apply organizational pressure on other firms, but to standardize the working conditions of the employees of [the signatory] contractors." 226 Hence, the goal of a subcontracting agreement in the prehire context is not to organize but to protect the interests of existing union members.

Moreover, the Connell holding reflected a desire to prevent unions from wielding unlimited power to organize through subcontracting agreements. ${ }^{227}$ The prehire agreement, as a precondition for protection under the proviso, meets this need. Section $8(b)(7), 228$ which provides a "comprehensive code" governing recognitional picketimg, ${ }^{229}$ is fully ap-

223. 635 F.2d at 875.

224. Id. at 873. See also NLRB v. Local 103, Iron Workers, 434 U.S. 335, 348-49 (1977).

225. 421 U.S. at 631.

226. $635 \mathrm{~F} .2 \mathrm{~d}$ at 873 (emphasis in original).

227. Id. at 871-72. The Connell Court felt compelled to deny protection under the proviso to the Plumbers' subcontracting agreement in order to avoid opening a "glaring loophole" in Section 8 's restrictions on top-down organizing. 421 U.S. at 616. To understand what the Connell Court meant by a "glaring loophole," it is necessary to analyze the interaction of several provisions of section 8 .

Section $8(b)(7)(C), 29$ U.S.C. $\S 158(b)(7)(C)(1976)$, regulates recogintional picketing by restricting it to a reasonable time not to exceed thirty days unless a petition for an election under section 9(c), 29 U.S.C. \& 159(c) (1976), is filed. Section 8(b)(4)(B), 29 U.S.C. § 158(b)(4)(B) (1976), prohibits unions from picketing to coerce an einployer to cease doing business with any other person. Section 8(b)(4)(A), 29 U.S.C. \& 158(b)(4)(A) (1976), prohibits unions from picketing to secure an agreeinent that is unlawful under section $8(e)$.

These provisions form a carefully designed web to limit union efforts at top-down organizing. See Connell Constr. Co. v. Plumbers Local 100, 421 U.S. at 632. The Plumbers sought to organize froin the top down, contrary to the policy of section 8. Section $8(b)(7)(C)$, however, did not apply to the Plumbers' subcontracting agreeinent. Because the union disclaimed an interest in representing Connell's employees, its picketing was not recoguitional. $C f$. Dallas Bldg. \& Constr. Trades Council v. NLRB, 396 F.2d 677 (D.C. Cir. 1968) (Trades Council picketing for a subcontracting agreement for the crafts that belonged to the Council was held to be subject to section $8(b)(7))$. Section 8(b)(4)(B) did not apply; it prohibts picketing aimed at forcing an employer to cease doing business with a specific person but does not prohibit picketing to secure a general agreement not to do business with, for example, nonunion firms. If section 8(b)(4)(A), the scope of which depends on section 8(e), did not apply, the union's conduct would thus be permitted to slip through the statutory scheme-creating the "glaring loophole" that the Connell Court feared. The Court therefore faced the question whether section 8(e) should be construed to permit subcontracting agreements absent a collective bargaining relationship. To avoid undermining the policy against top-down organizing, the Court held that section 8(e) should not be so construed. 421 U.S. at $632-33$.

228. 29 U.S.C. $\S 158(b)(7)(1976)$.

229. See NLRB v. Drivers Local 639, 362 U.S. 274, 291 (1960). 
plicable to agreements under section $8(f) .{ }^{230}$ A union seeking a subcontracting agreement as a term of a prehire contract thus cannot exert unlimited pressure to organize nonunion subcontractors.

Having decided that a section 8(f) contract brought a subcontracting agreement within the scope of Connell, the Donald Schriver court then determined the scope of a permissible agreement. At the outset the court endorsed the view that the proviso enables unions both to avoid job-site friction and to maintain contract standards. ${ }^{231}$ Broad subcontracting agreements that apply beyond particular job sites protect contract standards and accord with the scope of section 8(f) agreements, which apply at unspecified future job sites. ${ }^{232}$ Tlius, a valid subcontracting agreement may apply at job sites that are as yet unforeseen. In addition, it may. restrict subcontracting in crafts otlier than that of the signatory union's craft because of the job-site friction policy. ${ }^{233}$ The court reaclied this conclusion by looking to the literal language of the proviso, ${ }^{234}$ its legislative history, ${ }^{235}$ the longstanding use of broad subcontractimg agreements, ${ }^{236}$ and the compatibility of subcon-

230. See NLRB v. Local 103, Iron Workers, 434 U.S. 335 (1978). Before a union attains majority status, a section $8(f)$ agreeinent does not have binding force on an einployer; the union is therefore subject to section 8(b)(7)'s limitation on recognitional picketing. From the perspective of enforcement, a minority union with a prehire agreement is in the same position as a union that has no collective hargaining agreeinent at all. See NLRB v. Local 103, Iron Workers, 434 U.S. 335 (1978).

231. 635 F.2d at 880 .

232. Id. at 881. An employer does not commit an unfair Iabor practice by refusing to comply with the terms of a section 8(f) agreement at a specific job site, however, until the union demonstrates majority support. See NLRB v. Local 103, Iron Workers, 434 U.S. 335, 346 (1978). Thus, a union cannot enforce a subcontracting agreement included in a section $8(\mathrm{f})$ contract by picketing or by filing unfair labor practice charges until it obtains najority support at a particular job site. The contract might be enforceable in court, however, even without majority support. See Contractors Health \& Welfare Plan v. Associated Wrecking Co., No. 80-1191 (8th Cir. Jan. 21, 1981). In Associated Wrecking, the court held that a union may enforce the fringe benefits provisions of a prehire agreement in a federal court action under $\$ 301$ of the Taft-Hartley Act, 29 U.S.C. \& 185 (1976), despite the absence of inajority support for the union. This holding conflicts with dicta in Local 103. See 434 U.S. at 351-52.

233. 635 F.2d at 883-84. The court noted that restrictions on subcontracting outside of the craft that has signed the subcontracting agreement might fall outside the proviso if no members of a signatory craft are to be employed on a given job site. $I d$. at $881 \mathrm{n} .29$.

234. Id. at 877. The court refused to inake inroads on the statute's literal language without a compelling policy. Id.

235. Id. at 878-79.

236. Id. at 879-80. The court stressed the fact that no case before or after the enactment of the construction imdustry proviso struck down a subcontracting agreennent because it was not limited to the cominon-situs situation. $I d$. at 879 . Additionally, a study indicated that such agreements were prevalent in 1959. Id. See Lunden, Subcontracting Clauses in Major Contracts (pts. 1-2), 84 MONTHLY LAB. Rev. 579, 715 (1961). 
tracting agreements with the working conditions in the construction indnstry. ${ }^{237}$

Finally, the court affirmed the validity of subcontracting agreements that designate a specific union that a subcontractor must recognize. Interunion strife may disrupt job-site work to the same extent as union-nonunion strife. The court agreed with the Court of Appeals for the Ninth Circuit on this issue. ${ }^{238}$

Donald Schriver carefully examined the actual patterus of bargaining in the construction industry before upholding the broad subcontracting clauses before it. The court also returned to the legislative history to support its views. These fresh inquiries brought a new perspective to the construction industry proviso. Because Donald Schriver explored the empirical basis for extending proviso protection to broad subcontracting agreements, it provides a practical reconciliation of the National Labor Relations Act and the construction industry bargaining patterns.

\section{The Conflict Between Donald Schriver and Connell.}

Connell's reading of the proviso did not escape the Donald Schriver court. The court sought, however, to reduce Connell's statement of the purposes of the proviso to dicta. Donald Schriver asserted that the Supreme Court merely speculated about a number of possible reasons for the proviso but found it unnecessary to select one because the Plumbers could not connect their conduct to any of the suggested reasons. ${ }^{239}$ Even though Connell did not settle on a simgle policy, however, its discussion of these policies was necessary to the result of the case. ${ }^{240}$ Donald Schriver atteinpts to finesse Connell's doubts concerning the congressional notive of preserving a pattern of bargaining, and Connell's apparent preference for a common-situs approach to the proviso, ${ }^{241}$ by stating, "The Supreme Court . . . did not determine the purpose behind the construction industry proviso."242 This strategy cannot conceal the conflict between Donald Schriver's elaborate examination of subcontractimg practices in the construction imdustry and Connell's explanation of the proviso as a narrow measure to reverse Denver Build-

237. 635 F.2d at 880-81. The court emphasized that continuity of fringe benefits from job site to job site would be extremely difficult to secure without subcontracting agreements. The court also reasoned that the construction worker is generally indifferent whether he works for the general contractor or the subcontractor as long as he works under union conditions. Id.

238. Id. at 884-85.

239. Id. at 871-72.

240. Without establishing a range of policies behind the proviso, the Court could not have found that the Plumbers' agreement fell outside the proviso.

241. See notes $96-100$ supra and accompanying text.

242. 635 F.2d at 877 n. 25 . 
ing Trades. ${ }^{243}$ Although Connell may not have given enough weight to certain portions of the legislative history, the interpretation that Connell has given to the proviso may not be removed so easily.

More fundamentally, the holding of Donald Schriver clashes with the implications of Connell for top-down organizing. Though the Donald Schriver court noted the emphasis that Connell placed on the policy against top-down organizing, it held that the policy did not apply to a subcontracting clause in a prehire agreement. ${ }^{244}$ The court stated that such an agreement would be lawful, even if it had the sweeping organizational effect of the Connell agreement, because its purpose is simply to protect the union members' opportunities to work under union conditions. ${ }^{245}$

Connell, however, seems to leave little room for any top-down organizational impact in its analysis of the proviso's purpose. The Court not only imphed that the proviso was designed primarily to permit the avoidance of work stoppages due to Denver Building Trades problems, but also emphasized that section 8(f) was the only consideration given to construction unions seeking to widen their base. ${ }^{246}$ The Connell Court nay have attached exaggerated importance to the policy against top-down organizing in limiting the construction industry proviso. ${ }^{247}$ Nevertheless, Connell might imply a denial of proviso protection to a subcontracting agreement with a vast, if unintended, potential to organize froin the top down. ${ }^{248}$

243. See generally NLRB v. Denver Bldg. \& Constr. Trades Council, 341 U.S. 675 (1951). See notes 29-36 supra and accompanying text.

244. 635 F.2d at 873-74. The contractors suggested at oral argument that section $8(b)$ (7) fails to stem top-down organizing in the construction industry, arguing that "it is not an effective remedy because it isn't just picketing for 30 days . . . [T] the union can picket for 75 and 100 days . . ." Id at $876 \mathrm{n}$.24. For the Board's interpretation of section 8(b)(7) see Hod Carriers Local 840 (Blinne Constr. Co.), 135 N.L.R.B. 1153 (1962). See also NLRB v. Local 103, Iron Workers, 434 U.S. 335 (1978) (picketing to enforce a section 8(f) prehire agreement before the union has attained majority support is regulated by section $8(\mathrm{~b})(7)$ ). The Donald Schriver court pointed out that the contractors' criticisn attacks the remedy provided by Congress. 635 F.2d at $876 \mathrm{n} .24$. Nevertheless, the efficacy of this remedy might well be considered in deciding whether to tolerate the top-down organizing impact of subcontracting agreements even within a prehire agreement.

245. 635 F.2d at 873 .

246. 421 U.S. at 629-33. See notes 98-106 supra and accompanying text.

247. See notes 111-39 supra and accompanying text.

248. It is also not clear that the organizational impact of subcontracting clauses is unintended. See Office of Construction Industry Services, Labor Management Services adminisTRATION, U.S. DEP'T OF LABOR, 1979 ANNUAL REPORT OFFICE OF CONSTRUCTION INDUSTRY SERviCES 4. The report states in part: "In March 1978, the Building and Construction Trades Department established a formal organizing program in the Los Angeles area . . . The program is very broad and involves both top-down and bottom-up organizing. . . . The organizing operation netted over 10,000 new members for the building trades umions in 1978." Id. 


\section{CONCLUSION}

In Donald Schriver the construction industry proviso has finally been given a proper analysis. That case has supplied the economic framework that is essential to grasp the purposes of the proviso. Prior to Donald Schriver, courts had been narrowing the proviso to fit the purpose of avoiding job-site friction. Donald Schriver demonstrates, however, that Congress had broader concerns when it partially freed construction unions from the net of anti-secondary provisions of the labor laws. To protect work opportunities and to standardize working conditions, unions must have the power to compel general contractors to adhere to negotiated terms, even if the general contractors choose to employ their construction workers through the medium of a subcontractor.

The paradox of this conclusion is that it conflicts with other wellestablished labor policies. Union work opportunities can be ensured through subcontracting agreements only by forcing nonunion subcontractors to recognize a union in order to secure work on a job site. Whether the National Labor Relations Act permits this effect is a question of statutory mterpretation; whether it ought to sanction it is a judginent that belongs to Congress. In the absence of a clear congressional statement to the contrary, the balance struck in Donald Schriver is fair, permitting construction unions to maintain the working standards of their members while limiting their power to exert pressure on nonunion firms. To the extent that this balance conflicts with the implications of the Supreme Court's decision in Connell Construction Co. v. Plumbers Local 100, the Supreme Court should resolve the inconsistency by endorsing the position of the Donald Schriver court.

Michael R. Dreeben 